Western University Scholarship@Western

Centre for the Study of International Economic

Centre for the Study of International Economic

Relations Working Papers

Relations

1986

\title{
A Canadian Regional General Equilibrium Model and Some Applications
}

Rich Jones

John Whalley

Follow this and additional works at: https://ir.lib.uwo.ca/economicscsier_wp

Part of the Economics Commons

Citation of this paper:

Jones, Rich, John Whalley. "A Canadian Regional General Equilibrium Model and Some Applications." Centre for the Study of International Economic Relations Working Papers, 8621C. London, ON: Department of Economics, University of Western Ontario (1986). 
THE CENTRE FOR THE STUDY OF INTERNATIONAL ECONOMIC RELATIONS

WORKING PAPER NO. $8621 \mathrm{C}$

A CANADIAN REGIONAL GENERAL EQUUILIBRIUM

MODEL AND SOME APPLICATIONS

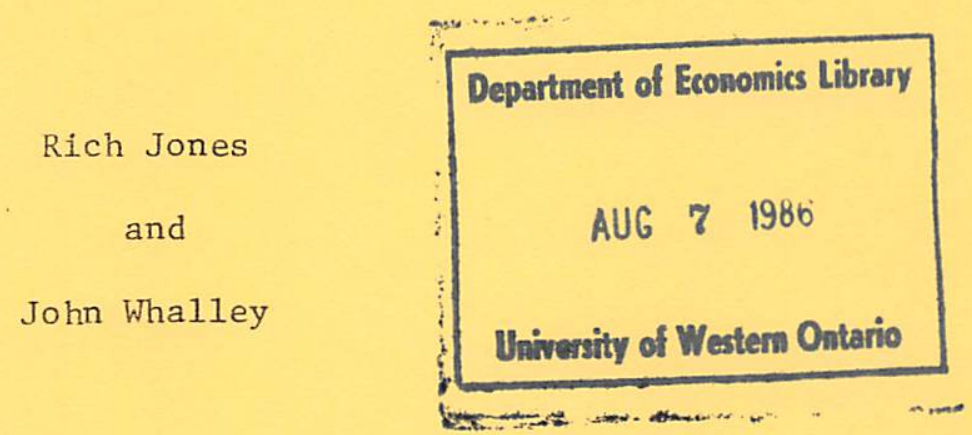

This paper contains preliminary findings from research work still in progress and should not be quoted without prior approval of the authors.

DEPARTMENT OF ECONOMICS

THE UNIVERSITY OF WESTERN ONTARIO

LONDON, CANADA

N6A $5 \mathrm{C} 2$ 


\title{
A CANADIAN REGIONAL GENBRAL EQUILIBRIUIA
}

MODEL AND SOME APPLICATIONS ${ }^{1}$

by Rich Jones and John Whalley

\author{
Department of Economics \\ Social Science Centre \\ The University of Western Ontario \\ London, Canada N6A 5C2
}

Department of Econonics Library

AUG 7 198

June 1986

\footnotetext{
$1_{\text {We are grateful to the Social Sciences and Humanities }}$ Research Council, Ottawa, for their support of this nodelling work. This model has also been used in a research project supported by the Royal Commission on the Economic Union and Development Prospects for Canada.
} 


\section{INTRODUCTION}

In this paper we describe a numerical regional general equilibrium model of Canada, constructed to aid in the evaluation of regional impacts of both federal and provincial policies. The motivation underlying model construction is that there are significant regional dimensions to most policy issues in nearly all countries, and at present no wholly satisfactory general equilibrium models exist for evaluating them. The present model aims to go some way towards filling this wider need for a policy evaluation tool for such issues, and is therefore also of interest outside the immediate Canadian context. Its more detailed application to Canadian debates on the impacts of various features of federal-provincial arrangements is described in thalley and Trela (1986).

In the sections that follow we outline the basic model, summarize the model variants currently available, describe the ways in which data and elasticity values have been used to implement the model, and present some calculations of the regional impacts of policies used by both federal and regional levels of government in Canada. An appendix contains a statement of the model in full algebraic form.

\section{AN APPLIED GENERAL BQUILIBRIUI REGIONAL MODEL OF CANADA}

\section{Overview}

Our Canadian regional model is closely related to the applied general equilibrium models already available for the analysis of taxation and international trade policy issues (see the survey paper by Shoven and Whalley [1984]). A series of regions are specified each with a demand and production structure, and interregional trade in comodities takes place. In contrast to available international trade models, a series of further interactions (such as intergovernmental transfers) occur between regions. Also, the assumption 
of interjurisdictional factor imobility is not made here; a quite different treatment of partial factor mobility between regions is used.

The main features of the basic variant of the model are described in Table 1. A single period (static) model is used which contains six Canadian regions: Atlantic Canada, Quebec, Ontario, Manitoba/Saskatchewan, Alberta, and British Columbia. Both interregional trade in goods, and factor flows between regions occur. A seventh region, the rest of the world (ROW) appears in the model and all Canadian regions engage in international trade with this region.

Each Canadian region contains 13 industries. ${ }^{1}$ These use both primary factors (capital services, labour services, and natural resources) and intermediate products (other commodities) as inputs. Regionally provided public services are included as one of the 13 produced goods in each region; this is the only good which is neither interregionally nor internationally traded. The ROW also has 13 industries, but production involves only capital and labour services (i.e. there are no intermediate inputs or natural resource inputs).

The 13 produced goods in each region are treated as qualitatively different from similar commodities produced either in other regions or abroad. This is the "Armington assumption" (from Armington [1969]), widely used in international trade applied general equilibrium analysis. The reasons for also adopting this treatment here are the same as in the international trade models; $i . e$. the presence of cross hauling in interregional trade statistics (the same good is being shown as imported and exported by the

1These are: agriculture; fishing and trapping; mines and quarries; food, beverages and tobacco; light manufacturing; lumber, paper and printing; metal and machinery; vehicles; energy; transportation; utilities; personal and business services; and regional government services. 
Table 1

Sumary of Kain Features of the Basic Variant of the Canadian Regional General Bquilibrium Hodel

1. Regional Structure:

2. Production:

3. Demands:

4. Taxes and Transfers:
Six Canadian Regions identified along with the rest of the world (Atlantic, Quebec, Ontario, Manitobal Saskatchewan, Alberta, British Columbia, ROW).

Each of six regions in Canada produces 13 goods using both primary factors and intermediate products as inputs. Thirteen goods are also produced abroad. Bach of the 13 goods is assumed to be qualitatively different both across regions and internationally. (Armington Assumption.)

Final demands in each region are derived from maximizing a five-level nested CES/LES utility function subject to a budget constraint. Intermediate demands reflect cost minimization across sources of supply.

Both regional and federal levels of government are identified, each with taxes and expenditures. Intergovernmental transfers are incorporated.

5. Model Treatment of Factor Mobility:

(i) capital services

(ii) labour services

(iii) resources
- variant. (a) capital is interregionally and intersectorally mobile, but internationally immobile.

- variant (b) capital is interregionally, intersectorally, and internationally mobile.

- assumed internationally immobile, intersectorally mobile within any region, but interregionally partially mobile; labour is homogeneous across regions, but consumers have locational preference leading to partial mobility between regions (see later explanation in text).

- assumed internationally and intersectorally immobile. 
same region). It is also easier to incorporate interregional trade elasticities within the model specification using the Armington assurnption. 2

On the production side of the model, three different primary factors of production appear: capital services, labour services, and natural resources. To simplify things, only two of these appear as inputs in the production function in any industry in any region. Non-energy industries use only capital and labour services as factor inputs; energy industries use natural resources and labour services as inputs.

Two alternative treatments of factor mobility are available for capital services. In variant (a), capital is assumed to be both interregionally and intersectorally mobile within Canada, but internationally immobile. Variant (b) differs from this treatment in also allowing international mobility of capital. These two variants reflect the fact that the literature is not conclusive as to whether or not perfect international capital mobility is a reasonable assumption to make for countries such as Canada, ${ }^{3}$ even though many economists consistently use it. The treatment adopted for capital mobility is important when assessing the impacts of regional policies designed to promote investment in particular regions. With perfect international capital mobility, policies which attempt to promote investment in one region over another will have no effect on investment in other regions. With either

\footnotetext{
2The extent to which regions can change their terms of trade and shift the burden of such policies as regional taxes onto other regions depends critically upon the values used for substitution elasticities among the Armington products. These, in turn, imply price elasticities in interregional trade.

${ }^{3}$ See Feldstein and Horoika (1980), and Harberger (1980).
} 
full or partial international immobility of capital, regional investment policies will affect the allocation of capital in all regions.

The model treatment of interregional labour mobility is more complex since labour is assumed to be internationally imnobile, intersectorally mobile, but interregionally partially mobile. The treatment adopted involves individuals trading off differences in income associated with locating and working in various regions, against their locational preference for remaining in their region of origin. Partial mobility of labour between regions is incorporated through an assumed distribution of individuals within any region by their intensity of locational preference. Thus, in response to a change in relative regional incomes, only a portion of any region's population migrates.

This partial mobility treatment is adopted for a number of reasons. The most important is that a model in which labour is perfectly mobile between regions is not particularly useful in analyzing whether, and by how much, regions gain or lose as a result of specified changes in either national or regional policies, since regions, as such, are not defined. Treating labour as completely immobile between regions allows interregional distributional effects of policies to be captured, but excludes all the efficiency issues associated with the regional movement of labour which have been so heavily stressed in recent literature on fiscal federalism. 4

Finally, resource inputs are treated as internationally and intersectorally immobile. The key resource inputs appear in oil and gas (energy) industries, in resource rich Western regions.

On the demand side of the model, products produced both within-region and out-of-region appear in final demand functions in each region, including 
ROW. Demands are based on utility maximization, with each region maximizing a nested CES/LES utility function subject to a regional budget constraint. 5 The hierarchy within the nesting structure is an important element in model design, and is described below.

Each regional budget constraint includes capital, labour, and resource income received by residents, along with intergovernmental transfers received from the federal government and federal government transfers to persons. Since there is no data available in Canada (or any other country to our knowledge) on interregional patterns of asset ownership, we make the strong assumption that in the base (pre-policy change) case considered in the model, capital and resource incomes originating in a region also accrue to residents of that region. Taxes paid within a region enter the region's budget contraint on the expenditure side, and they generate lump sum transfers which reappear as regional income. Intermediate demands reflect cost minimization across within-region and out-of-region sources of supply, and also involve a nested CES production structure (described below).

Integrated into this treatment of production, demand, and interregional and international trade, are a series of Canadian policies each of which has regional impacts. These policies include nation-building policies which promote interregional trade at the expense of international trade (tariffs, energy price controls, transport policies); financial arrangements between different levels of government; and interregional barriers to flows of goods and factors. Also included are tax collections and expenditures of both regional and federal governments (including intergovernmental transfers). These all affect the equilibrium produced by the model, and when changed

${ }^{5}$ In the model the federal government also has final demands; this aspect of the model is discussed later. 
induce behavioural changes by both producers and consumers in all regions.

\section{DEMAAND SIDE OF THE MODEL}

The CES nesting structure used for each region in the final demand portion of the model for each region is outlined in Table 2. At the bottom level, substitution occurs across other regional sources of supply for each of the interregionally traded goods. In the case of food, for instance, this level allows for substitution in each region between food supplied by the other five regions within Canada. At level four, substitution occurs between composite out-of-region, and within-region goods. In the case of food, this level defines a composite Canadian food bundle for consumption in the region. Substitution at the third level is between imports and comparable domestic goods, (i.e. imported food and the composite Canadian food available for regional consumption). This yields composites for each of the 12 traded goods. At the second level, substitution occurs among 11 non-energy composites, each involving a similar aggregation over levels five through three in the nesting hierarchy, and the particular region's nontraded public service commodity. Finally, at the top level, substitution takes place between the aggregate non-energy composite from level two, and a composite energy good aggregated in a similar way across levels 3 through 5 .

It is the bottom three levels of substitution in this hierarchy which contain the elasticity values which are most important for model results on the regional impacts of policies. Blasticities of substitution at level three largely determine the national import price elasticities of demands for each imported good. These elasticities determine the extent to which tariffs or other national trade policies cause changes in the composition of consumption between domestic and foreign sources of supply, and hence influence the 
U

Elasticity Designation

\section{Level 1}

$$
\begin{aligned}
& \text { (Substitution } \\
& \text { between energy } \\
& \text { and non-energy } \\
& \text { composites) }
\end{aligned}
$$

\section{Leve1 2}

(Substitution among

11 non-energy

private good

composites and non-

traded regional

public services)

\section{Leve1 3 \\ (Substitution between imports and \\ domestic composite)}

Level 4

(Substitution

within-region

and out-of-region)

\section{Level 5}

(Substitution across other regional sources of supply)
C

(Composite Non-Energy Good)

Region Specific Public Services

Imports

Within Region
B

(Composite Energy Good with Similar Aggregation structure Across Levels 3 to 5)

11 Non-Energy Good Composites

of

(For each of the including energy.)

Domestic Composite

of

Out-of-Region

o8

5 other regional sources of supply 12 traded goods, op 
national, and ultimately interregional, terms of trade. Elasticity values at level four determine the strength of comparable effects across regions. For instance, if a region puts in place policies designed to give preference to within-region suppliers or uses other regional barriers to trade, the extent to which the region's terms of trade will improve will depend upon these elasticities.

Level five elasticities determine the ease with which substitution occurs between sources of supply from other regions. These are important in determining the export price elasticities which regions face, since they reflect substitution elasticities across out-of-region sources of supply in all other regions.

If regional export price elasticities are high, then regions do not have any significant ability to export taxes and improve their interregional terms of trade through taxes on interregional exports. Were level five substitution elasticities not to be separately specified in the model, this would mean that the level four substitution possibilities would apply to all regional sources of supply, including those from within the region. Having the capability for different elasticities of substitution at these two levels allows the model user to specify high export price elasticities for any region while regions may simultaneously have lower import price elasticities in interregional trade. Beyond the bottom three levels, level two incorporates substitution possibilities between non-energy composite goods. Level one involves elasticities of substitution between non-energy and energy goods, reflecting a focus in the model on an ability to analyze regional dimensions of energy pricing issues in Canada. 
The nesting structure is somewhat different for the Row. At level three, substitution occurs between ROW supply of any good and the corresponding Canadian composite. Elasticities at this level determine the import price elasticity of demands for each good in ROw. Level four is not applicable to the ROW structure, while level five involves substitution over the Canadian regional sources of supply for each good. Elasticities at this level are important in determining the export price elasticities which individual Canadian regions face in trade with the ROW.

\section{ERDERAL AMD REGIOMTAL GOVBRRTEINTS}

An important difference between this model and other applied general equilibrium models is the separate treatment of a federal government and six Canadian regional governments. In this model, the federal government imposes taxes on and distributes subsidies to the six regions, reflecting the national policies included in the model. The federal government also makes transfers to both individuals and regional governments. As well, the federal government purchases goods directly from the regions and from the ROW. These purchases are based on utility maximization, with the federal government maximizing a nested CES/LES utility function subject to its budget constraint. The nesting structure is similar to that for the ROW, but since the federal government produces no goods, the level involving substitution between own and other region goods is not applicable. Thus, the federal government is modelled as an eighth trading region which only imports goods from other regions.

The federal government budget constraint includes income from government-owned capital, tax revenues collected in the regions, minus subsidies and transfers. The federal government pays no federal or regional taxes on its purchases. 
Modelling the federal government as a utility-maximizing agent which produces no output ignores the issue of public goods. While this simple treatment is adopted in the basic model variant, Whalley and Trela (1986) also discuss model extensions which explicitly incorporate public goods. For space reasons, this model variant is not discussed here, and federal expenditures are modelled as having no direct effect on regional welfare through national public goods provision.

Regional governments are not modelled as agents with a demand structure separate from that of consumers in regions. Any revenues raised are assumed to be redistributed in lump sum form to regional consumers, whose preferences are defined over regional public sector services as well as other goods. Regional taxes collected and transfers from the federal government thus effectively appear in the budget constraints of consumers in the region. Regional government expenditures and services appear as purchases of the non-traded regional public services good in each region.

\section{PRODUCTION SIDE OF THE YODEL}

The production side of the model involves two types of inputs for each industry in each region: intermediate inputs and primary factors. 6 The model treatment of substitution between intermediate inputs is similar to that on the demand side of the model. Thus, in determining, say, intermediate input requirements for light manufactures in Ontario, the assumption is made that Ontario light manufacturing industries cost minimize in selecting their intermediate inputs. This first involves substitution between energy and non-energy composites. Using the energy composite as an example, the next stage involves substitution between imported and domestic energy; and within

6No intermediate production for the ROW enters the model specification. 
the domestic energy component there is substitution between within- and out-of-region energy. Finally, substitution occurs across the out-of-region sources of supply of energy.

At the primary factor level, the model uses two-input CBS value added functions for each industry in each region. These specify labour services and either capital services or resources as inputs. In all industries, except energy, there are no resource inputs; and capital and labour services are the sole primary factor inputs. For energy industries, resources and labour services appear as the two factor inputs. This treatment is adopted in part to simplify the computer code for the model by using only two factor inputs, and to minimize the complexities of using further nested functions for inputs at little cost in foregone realism.

\section{INTRRRBGIONAL LABOUR MOBILITY}

A novel feature of the model, and one which differentiates it from other applied general equilibrium models, is its treatment of labour mobility between regions. This is an important but somewhat complex feature of the model, and is presented in more detail in the appendix on model structure. Other modelling efforts which have been used to evaluate the impacts of national policies have usually focused on one of two polar assumptions, either perfect labour mobility between regions, or complete labour immobility. However, neither of these is entirely appropriate in an evaluation of regional impacts of policy changes. With perfect labour mobility individuals have no direct association with specific regions, and the issue of whether regions gain or lose from policy changes has little meaning. On the other hand, effects of policies which induce migration between regions are not captured under an assumption of interregional labour immobility. 
Because of the desire to analyze the regional impacts of policies on different groups of residents of regions within Canada, the model treatment used here incorporates location specific preferences. We assume that there is a distribution of individuals within each region who differ only by their intensity of locational preference. Their utility function parameters reflect this difference in a systematic way across the original (pre-policy change) population in each region.

The utility function for any agent in any region is specified as the maximum of two separate subutility functions. This is described in section 1 of Table 3. The $U_{i}^{H}$ function gives the utility from consuming a given bundle of goods if individual $i$ remains in his original region. The $U_{i}^{F}$ function gives the utility from consuming the same bundle of goods if the individual moves outside the region. If it is assumed that all individuals are identical within any region, then in response to a changed income differential between regions all individuals in a region would either leave or stay, and no partial labour mobility would occur. To incorporate partial mobility, the $U_{i}^{F}$ function is assumed to vary systematically across individuals. These are ranked in terms of their intensity of locational preference. The $U_{i}^{F}$ function thus incorporates the locational penalty which individuals are assumed to bear should they leave and which is of increasing severity across individuals. To simplify things, the strong assumption is made that an individual leaving one region and moving to another maintains the same preference structure across goods associated with all residents in his original region. Individuals do not therefore acquire the preferences of residents of the other region after relocating. 


\section{Table 3}

Sodel Treatment of Partial Labour Mobility

1. Location specific preferences

$$
u_{i}=\max \left[U_{i}^{H}(x), U_{i}^{F}(x)\right]
$$

$$
\begin{aligned}
v_{i}^{H}= & \text { utility for individual } i \\
& \text { from consuming bundle of } \\
& \text { goods } x \text { inside region. } \\
v_{i}^{F}= & \text { utility for individual } i \\
& \begin{array}{l}
\text { from consuming bundle of } \\
\text { goods } X \text { outside region }
\end{array}
\end{aligned}
$$

2. Indirect utility functions

$$
\begin{aligned}
& \bar{U}_{i}^{H}=I^{H} \cdot g(P) \\
& \bar{U}_{i}^{F}=I^{F} \cdot g(P)
\end{aligned}
$$

$$
\begin{aligned}
I^{H}= & \text { income if located in own } \\
& \text { region. } \\
I^{F}= & \text { income if located outside } \\
& \text { own region. } \\
g(P)= & \text { true cost of living (price) } \\
& \text { index for consumption by } \\
& \text { individuals from the } \\
& \text { region. } P \text { is assumed to be } \\
& \text { the same over all regions. }
\end{aligned}
$$

3. Distribution of individuals within regions by intensity

of preference for remaining in the region

$$
u_{i}^{F}=\bar{u}_{0}^{F}-(\delta \cdot i) \quad i=0, \ldots, v
$$

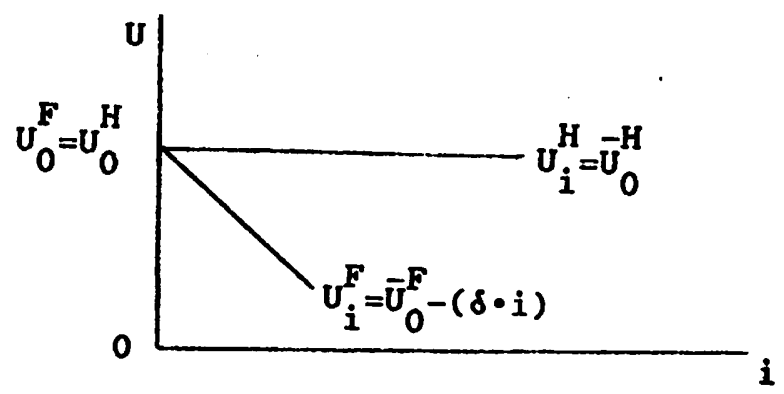

Individuals trade off income differentials across regions against intensity of locational preference given by $\delta$. As drawn, individual 0 is the only individual on the margin between staying and leaving the region.

\section{Implication of Reduction in $\mathrm{I}^{\mathrm{H}}$}

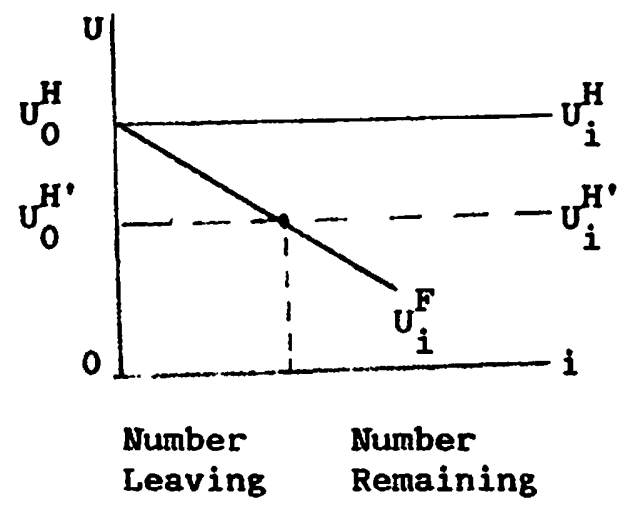

Individual on margin shifts beyond individual 0 . Size of out migration determined by slope of UF function. 
These features, and an assumption that goods prices faced by each region are the same, allow us to employ the two indirect utility functions shown in Section 2 of Table 3 in determining an individual's location decision. $\vec{U}_{0}^{H}$ gives the utility from goods consumption if individual 0 remains in the region. Since the subfunction $U_{i}^{H}$ does not reflect any locational preference (there is no penalty for staying in the home region), $u_{i}^{H}=\bar{u}_{0}^{H}$.

Location preferences enter through the function $U_{i}^{F}$, which varies systematically across the initial population within any region. The parameter $\delta$, in Section 3 in Table 3 , reflects the utility penalty any individual incurs under out migration. The product of the parameter $\delta$ and the index $i$ defines the intensity in locational preferences as one moves from 0 to $\mathrm{J}$ through the index of the original population in any region. In the original equilibrium situation to which the model is calibrated, only the first individual $(i=0)$ is on the margin between staying and leaving. All others are beyond the margin and have an unambiguous preference for remaining in their region of residence. If relative incomes change across regions, then some residents will be induced to relocate because the income differential across regions will outweigh their locational preference.

In Section 4 of Table 3, when a decrease in income in the home region occurs, the $U_{i}^{H}$ function shifts down as indicated, and some of the individuals initially in the region leave. Outmigration would also occur when an increase in income in other regions results in an upward shift in the $v_{i}^{F}$ function. In both cases, the size of outmigration depends upon the slope of the $U_{i}^{F}$ function, which in turn depends on the parameter $\delta$. A 
further portion of the model (discussed in the appendix) specifies how individuals leaving a region locate in other regions. In the simplest approach, a fixed coefficient treatment is used, but a CES distribution function could also be used.

In this way the model can be used to capture the effects on migration decisions of regional differences in wage rates, equalization, and regional taxes on resource rents. A complete model implementation of this approach to labour mobility could incorporate migration effects of all regional taxes rather than only resource taxes, and all the regionally concentrated federal policies which appear in the present model specification. Including all of these in the interregional migration treatment in the model is, however, complex from a computational point of view.

\section{FORBIGN TRADE}

The main features of the model treatment of foreign trade are the Armington assumption and the treatment of international factor mobility, both of which have been discussed earlier.

The specification of behaviour by foreigners in the model is also especially important. Whalley and Yeung (1984) have shown, for instance, that the treatment adopted for the behaviour of the Rest of the World in single economy general equilibrium models can crucially affect their behaviour, since this determines whether the economy in which one is interested is modelled as a price taker or price maker. In the present model the behaviour of foreigners involves both their production and demand. In the data used to calibrate the model the output of each industry in the ROW is set at approximately ten times the value added in the industry for all Canadian regions combined. This is done in order to approximate Canada's relationship with its largest trading partner, the United States. 
An external sector balance condition also appears as part of the characterization of equilibrium. This states that the value of imports plus the net imbalance on the capital account equals the value of exports, and is equivalent to stating that, as a country, Canada is always on its budget constraint in its international transactions. Two factors determine the international import-supply and export-demand elasticities which regions within Canada face: the elasticities of substitution between Canadian and foreign products in the ROW preferences, and the size set for ROW.

\section{TREATMENT OF POLICIES}

In addition to demand, production and the various other elements outlined in earlier sections, the model also incorporates a series of Canadian policy elements which have regional impacts. These include nation-building policies, intergovernmental transfers, issues associated with the economic union (such as interregional trade barriers), and various other policies including features of federal and provincial tax systems, and non-tariff trade restrictions. These policies are listed in Table 4 along with a brief indication of their model treatment.

In most cases, the model treatment of these policies is relatively straightforward. For instance, the tariff is treated as an ad valorem tax on imports into all regions in Canada, covering both final and intermediate demands and with rates varying across commodities. In other cases, the modelling of policies is more complex.

This is especially the case with energy policies, where a number of different features come into play. Royalties are incorporated as ad valorem regional taxes on inputs of resources (oil and gas) used in energy 
Table 4

Treatment of Key Policy Elements in The Kodel

Nation-Building Policies

Tariffs

Transportation Subsidies

Energy Policies
Mode1 Treatment

Ad valorem tax on imports (final and intermediate demands)

Subsidy on grain shipments from Western Canada

Provincial Royalties - ad valorem regional tax entering producer costs

Price Ceilings - ad valorem consumer subsidy, ad valorem producer tax

Exploration Grants - producer subsidies

Federal-provincial transfers calculated using explicit formulae

Federal-provincial transfers - equal amount per capita across regions

Cost-shared regional transfer programme

Ad valorem tariffs on imports from other regions in Canada

Subsidies to capital use within region

Ad valorem equivalent tariff on imports

Manufacturers sales tax modelled as ad valorem output tax

Manufacturing and processing incentive modelled as lowered corporate tax rates

Progressive federal income tax

Regional subsidies to capital use by industry within region

Agricultural output subsidies
Regional Development Programs

Agricultural Programs 
industries. Energy price ceilings are approximated by ad valorem consumer subsidies on energy which maintain consumer prices below world prices, and ad valorem producer taxes on energy products which lower the net of tax price received by producers to below world prices. The model also incorporates the Petroleum Compensation Charge used in Canada in the base year for the model to finance consumer subsidies covering the difference between domestic and world prices for imports. A further feature of Canadian energy policies modelled here are exploration and development incentive grants. These appear as producer subsidies, but the marginal effects of these policies on new exploration and development activity are not captured.

Transfers between the federal and provincial government are also incorporated in the model. Each program is specified in a different way. In the case of the equalization program, for instance, the explicit formulae used for the different tax bases are applied to 1981 data, and generate interregional transfers based on the shares of provincial tax bases and population. Possible changes in equalization can then be considered as policy variations in the model. Federal funding for health care and post-secondary education reflect an equal per capita grant to all provinces, and Federal welfare support (the Canada Assistance $P 1 a n$ ) is incorporated as the major cost-shared federal provincial transfer program. Interregional transfer effects generated by these programes thus enter the model.

Regional barriers to free goods flows between regions are incorporated through ad valorem tariffs on imports from other regions in Canada. This is not a wholly appropriate treatment of these policies since, in practice, they involve quantity and other restrictions on both exports to and imports from other regions, which are quite different from tariffs. Examples of these are 
regional supply management marketing boards, and preferential regional procurement policies, neither of which is equivalent to a tariff. Tractability is the main defence for the treatment adopted.

Regional capital market preferences, which involve subsidies by the regions on capital use by industry, are incorporated as part of the taxes and subsidies which apply to the capital use by industries. Regional taxes on capital income originating in industries within regions are lowered as a result of these subsidies; in some cases a net subsidy applies.

A final set of policies which enter the model are other tax and subsidy elements and non-tariff trade restrictions, all of which have regional effects. These include textile quotas, agricultural policies, and features of the Canadian federal tax system which have pronounced interregional impacts. For instance, the federal manufacturer's sales tax enters as an ad valorem sales tax on manufactures. Similarly, the manufacturing and processing incentive in the corporate tax appears as lowered corporate tax rates for manufacturing industries. Progressive national income taxes enter as differential average federal income tax rates by region. Regional development programs appear through regional subsidies to capital use. Regional impacts of agricultural programs also enter through federal subsidies to agriculture in each region.

\section{BQUILIBRIUY CONDITIOUS IN THE YODEL}

Once production, demand, and policy intervention parameters in the model are known, its equilibrium solution can be found. A general equilibrium in the model can be interpreted in the usual Walrasian sense as a set of prices for which all markets clear, but because of the more complex structure of this model relative to other applied general equilibrium models, the equilibrium conditions need to be more carefully discussed. 
In equilibrium, demand-supply equalities hold in each goods market (demands include both exports by and intermediate demands in any region), and demand-supply equalities hold in factor markets. In the case of the capital market, if capital is both nationally and internationally mobile, there is only one single capital market equilibrium condition. Where capital is internationally inmobile there are two separate capital market conditions, one in Canada and one abroad. In the case of resources, these are modelled as specific to Canada and its energy industries, and so a single demand-supply equality applies.

Since the endogenous migration features of the model result in different wage rates across regions, even though labour is homogeneous across regions separate labour market equilibrium conditions have to be satisfied in each region, plus an additional equilibrium condition in the Row. In addition, zero profit conditions must hold for each industry, both abroad and in all regions in Canada; budget balance conditions must hold for both the federal. government and each of the regional governments; and external sector balance conditions also hold.

\section{MODEL VARIANTS}

A series of model variants supplement the capability contained in the basic model described above. These allow for changes in the elasticity configurations used in demand and production functions and variants on factor mobility assumptions. ${ }^{7}$ There are also parameters which enable increasing

${ }^{7}$ As discussed earlier, capital can be made either internationally mobile or internationally immobile. The basic model variant involves the assumption that capital is internationally mobile. 
returns to scale to be incorporated in any industry production function in any region, using a parametric scale economy treatment. The model may also be used in reduced dimensionality format to reduce the execution costs of repeated solution. In reduced dimensionality format, the model is solved using only six goods ${ }^{8}$ in each region rather than the full thirteen.

III. IMPLEMENTING THE MODELLING APPROACH

To apply the model outlined in the preceding section to the evaluation of the interregional impacts of policies in Canada, parameter values must be specified for the equations appearing in the model, and it must be solved for competitive equilibria under the various policy changes considered. In specifying parameter values for the model, a calibration procedure similar to those used in other applied general equilibrium models is followed. This involves selecting a set of parameters for the equations of the model such that data which characterizes a benchmark (or observed) equilibrium can be reproduced as a model equilibrium solution.

The reasons for adopting this procedure are summarized in a recent paper by Mansur and Whalley (1984) on the numerical specification of applied general equilibrium models. They discuss the difficulties which arise with stochastic estimation of complete general equilibrium models. They note that it is usually not possible to write down a likelihood function for a complete general equilibrium model, and thus Full Information Maximum Likelihood (FIML) methods for complete model estimation are inapplicable.

\footnotetext{
${ }^{8}$ These are agricultural products, non-durable manufacturing products, machinery and transport equipment, energy and natural resource products, services from private sector, and services provided by the region's public sector.
} 
Calibration is most easily understood as the use of model equilibrium conditions and equilibrium data to solve for the parameter values used to represent the model equations. Only when the model is fully specified and a policy change incorporated is the model solved for a new equilibrium solution. Two types of equilibria therefore have to be distinguished in this use of general equilibrium models. One is 'observed' or 'benchmark' equilibria which are given from data and to which the model is calibrated (and thus do not need to be computed); the second is 'new' or 'counterfactual' equilibria which are computed as model solutions under changes in policy.

Elasticity estimates enter this calibration process by serving as identifying restrictions, allowing the other parameter values to be calculated. Different elasticities produce changed values for the other model parameters, and thus selecting appropriate elasticity values is central to the model specification process. A series of adjustments to basic data are also necessary when constructing the micro consistent 'benchmark' equilibrium data set used in calibration.

\section{MICRO CONSISTENT REGIONAL DATA}

The micro consistent regional data set for Canada which has been used in the regional general equilibrium model has 1981 as its base year. Nuch of the methodology used to construct this data follows that in an earlier paper by St-Hilaire and Whalley (1983) which describes the construction of a 1972 national data set for Canada developed for tax policy analysis. A more recent paper by St-Hilaire and Whalley (1985) gives details on the present regional data set. 
In this data set each region is viewed as a separate regional economy, but the links between regions differ from those recorded between nations in international data sets. Trade between regions is incorporated, but also appearing are tax payments from regions to the federal government, intergovernmental transfers received by regions, and federal government purchases of regionally produced goods. As a result, regions can be in either a surplus or deficit position in their transactions with the federal government. In turn, a surplus in transactions with the federal government can finance a deficit in a region's international and interregional trade.

Developing a regional accounting framework consistent with the general equilibrium model described earlier requires that all the transactions taking place in the separate markets and regions which comprise the national economy be recorded. Regional Input-Output Tables prepared by Statistics Canada provide the most detailed set of production and expenditure accounts available and, realistically, the only data upon which to base such an exercise. Statistics Canada has recently produced Provincial Input-Output (PIO) Tables for 1974 and 1979 as an extension to their National Input-Output Tables.

The 1979 tables are the major building block used in assembling the present micro consistent regional data set employed here. The PIo data are updated to 1981 using estimates of regional economy-wide aggregates from the Provincial Economic Accounts (PEA) compiled by Statistics Canada. The PEA also provide estimates of federal government transactions with individual regions, which are integrated into the data set.

The PIO Tables are similar in structure to economy-wide Input-output Tables. They contain two sets of interrelated accounts: a set of commodity accounts reporting the supply of and the demand for individual comodities, 
and a set of industry accounts showing the total gross output of each industry along with each industry's inputs in each region. In the first set of accounts, the supply of each commodity is reported as the amount produced by each industry plus the amount imported by the region. The demand for each commodity is reported as the amount used by each regional industry, plus the amount purchased by the final demand sectors and the amount exported. In the second set of accounts the gross output of each industry in the region is reported by comnodity. The total input of each industry is reported by commodity for intermediate inputs, and by type for primary inputs (i.e., indirect taxes, wages and salaries, and capital use costs). For each industry in each region, total production costs (value of intermediate plus primary inputs) equal the value of total production. Interregional and international trade data appear in separate trade flow matrices which record the flows of commodities between regions, and between regions and the Rest of the World.

There are, however, problems with these data. In contrast to the National Input-output Tables, where demand-supply equality conditions for each comodity implicitly hold, currently available regional tables show small imbalances, due in part to lack of data on inventory changes by commodity by region. Also, while the National Input-Output Tables are consistent with published measures of gross domestic product and expenditure at market prices from the National Income and Expenditure Accounts, PIO Tables are only constructed using these estimates as a reference point and strict consistency is not ensured. Furthermore, although data on interregional and international flows of goods are available, and are consistent with the supply and use of goods by region, data on interregional trade in services is weak. Even though the orders of magnitude involved are significant, a series of assumptions is 
therefore made concerning both the type of services that are traded and the interregional pattern of these flows.

PEA data have a longer coverage than PIO data, being available for years 1966-1981. In contrast to the National Income and Expenditure Accounts data which are estimated on a national basis, i.e., with incomes assigned according to the residence of the owners of factors of production, PEA data are estimated on a domestic basis allocating income to the region in which it is earned. This is also the approach used in determining the location of activity for the federal government and multiprovincial corporations and reflects what we have emphasized above, namely the absence of data on interregional asset ownership patterns.

\section{BLASTICITIES}

Besides the 1981 microconsistent data set, a further key input into the model are the elasticities of substitution which appear in the production and utility functions. Most important are four different sets of elasticities which affect commodity and factor flows in policy evaluations made with the model. These are: international trade elasticities (on both the import and export side), elasticities affecting interregional trade in commodities, elasticities determining substitution effects between energy and non-energy products in both final demands and intermediate production ${ }^{9}$, and elasticity parameters determining the size of interregional labour mobility effects induced by policy changes.

\footnotetext{
${ }^{9}$ The nesting structures in the model are identical for both final demands and intermediate production.
} 
The international trade elasticity values used are based on a compendium of estimates of trade elasticities due to stern et al. (1976). In their study they combine available estimates from existing sludies to provide both ranges and point estimates. 'Best-guess' estimates for Canada are based on the median point estimates for both the Canadian import demand elasticities and the export demand elasticities which Canada faces.

There are currently no available estimates for price elasticities in interregional trade in Canada. This is because there are no time series data on interregional trade flows on which to base such estimation. The approach used here for setting these paraneter values is the same as Hazeldine's (1979); that is, to assume that elasticities in interregional trade are the same as those in international trade. This approach is contentious, however, since a shares approach to elasticity determination, based on a region's share of international trade, would suggest that interregional trade elasticities would be considerably higher than international trade elasticity estimates. In turn, elasticities faced on the export side by any region which is small would presumably approach minus infinity.

A literature survey reported by Thirsk and Wright (1977) suggests that the elasticity of energy demand in Canada lies in the range of -0.4 to -0.6 , while the long-run price elasticity of supply is of the order of 1 to 1.5 . A more recent survey of energy demand elasticities by Kouris (1982) has also reviewed existing estimates, and contains comments on possible ranges of energy elasticity values, although not specifically for Canada. The Kouris study produces a range of energy elasticity estimates ( -.1 to -.5$)$, only slightly lower than that suggested by Thirsk and Wright. Estimates in this range are therefore used in specifying energy demand elasticity values in the general equilibrium model. 
other commodities appear in the demand functions in the general equilibrium model as a composite non-energy product, with substitution between the component products entering the composite. Since these are less crucial for results than other elasticities in the model, a Cobb-Douglas specification is used at this level of the nesting in the preference functions in all regions in the model. This is equivalent to setting all these elasticities to unity.

Elasticities of substitution between factor inputs in value added functions in each region in the model are set at .8 for all non-energy industries in all regions and .5 for energy industries. These are a little lower than the values reported in the survey paper by Caddy (1976) and used in Piggott and Whalley (1985), Whalley (1985), and Ballard, Fullerton, et al. (1985) for non-energy industries, but reflect the lack of a compatible classification link between that used in other studies and that in the present model. A strong assumption is made of identical values for similar industries in different regions.

In the factor flow area, two major separate sets of elasticities are specified: those for capital services and those for labour services. In the case of capital services, there are no good estimates of the elasticity of capital flows in response to differences in the rate of return either between regions or between Canada and the ROW. As a result, the two mobility assumptions discussed earlier are used: either capital is assumed to be both interregionally and internationally mobile, or it is treated as only interregionally mobile.

In the labour mobility area, the key parameters are those which determine the degree of partial mobility of labour between regions. These 
relate to the mobility formulation discussed earlier. The most recent study of interregional migration in Canada is that by Winer and Gauthier (1982) who analyze the effects of fiscal incentives on migration. However in specifying the interregional mobility component of the model, it is difficult to relate the Winer-Gauthier results directly to the mobility parameters which appear in the general equilibrium model. As a result, alternative values of the corresponding model parameters are chosen for compatibility with different assumptions on the elasticity of out-migration from a region with respect to interregional income differentials.

\section{APPLICATIONS OF THE HODEL}

In this section we report some counterfactual equilibrium calculations made with the model which yield estimates of the combined regional effects of key national and regional policies. They also serve to illustrate the application of the model to regional policy issues.

Employing the model for counterfactual policy analysis involves a similar approach to that of other applied general equilibrium models, i.e. calibration of the model to the interregional benchmark equilibrium data set as a first step, followed by a new equilibrium solution in the presence of a policy change. The new values of the model variables are then compared with those of the benchmark equilibrium, yielding measures of the counterfactual impact of the policy change.

In Table 5, results from three policy changes are reported. First, a series of federal government policies, including all federal taxes, transfers to individuals, and intergovernmental transfers, are replaced by a yield preserving uniform rate federal sales tax designed to keep federal real expenditures constant. The second policy change involves the simultaneous removal of comparable policies pursued by each of the regional governments in 
Table 5

Hodel Analyses of the Regional Impacts of Replacing

Federal and Regional Government Policies by a Uniform Rate Sales Tax

A. Welfare Effects in Terms of

Hicksian EV's (\$ mill. 1981) ${ }^{1}$

$\begin{array}{lrrrr} & \text { Case 1 } & \text { Case 2 } & \text { Case 3 } \\ \text { Atlantic Canada } & -4919 & 697 & -4052 \\ & (-24) & (3.4) & (-20) \\ \text { Quebec } & -8579 & 288 & -7826 \\ & (-12) & (0.4) & (-11) \\ \text { Ontario } & -951 & -189 & -5 \\ \text { Manitoba/Saskatchewan } & (-1) & (-0.2) & (-.0) \\ & -580 & -69 & -1035 \\ \text { Alberta } & (-2) & (-0.3) & (-4) \\ & 18331 & -2558 & 13530 \\ \text { British Columbia } & (51) & (-7.1) & (38) \\ & 804 & -200 & 1964 \\ \text { Total } & (2) & (-0.6) & (6) \\ & 4638 & -270 & 3431 \\ & (1.5) & (-0.1) & (1)\end{array}$

B. Interregional Net Labour Flows

(measured in $\$$ mill of labour income;

+ implies net inflow)

Atlantic Canada

$-4.4$

1.3

$-2.2$

Quebec

$-9.3$

0.9

$-4.2$

Ontario

$-13.7$

$-0.2$

$-1.7$

Manitoba/Saskatchewan

$-0.7$

0.4

$-1.4$

Alberta

British Columbia

30.2

$-3.9$

8.8

$\begin{array}{lll}-2.1 & 1.5 & 0.6\end{array}$

Case 1: Replacement of federal government tax/subsidy/transfer policies with yield preserving uniform rate federal sales tax.

Case 2: Replacement of each Canadian region's tax/subsidy policies with a yield preserving uniform rate regional sales tax.

Case 3: Policy changes in both cases 1 and 2 combined.

${ }^{1}$ Values in parentheses are Hicksian E.V.'s as a percentage of regional income (as a percentage of GNP for the Total). 
the model. A uniform rate sales tax is used for each region to maintain their revenues constant in real terms. The third change involves both of the above changes (including the relevant replacement taxes) being implemented together. Welfare gains and losses by region and the net migration into or out of each region are reported. Welfare effects are reported as Hicksian equivalent variations (EV's) in millions of 1981 dollars by region, the income equivalent of the welfare effect of the policy change on the region. The net labour migration into each region is reported as the total labour inflow from other regions minus the outflow from the region. The units are millions of 1981 dollars of labour income, and are measured in terms of the labour units implicit in the micro consistent data set (and described in more detail in the appendix).

Reported welfare effects by region have to be interpreted with some care because of the presence of interregional labour mobility in the model. The residents of a region before a policy change is instituted typically differ from the residents of a region after the policy change because the population of each region changes. In the results reported here welfare effects by region refer only to initial residents, that is, those who are in a region prior to the policy change.

By region, Alberta is the largest gainer in Table 5 from the removal of federal policies, with a gain of $51 \%$ of regional income. This large gain is due to the removal of both energy price controls and energy taxes under the federal government's National Energy Program in use in the early 1980's. These estimates thus reflect our choice of year for our micro consistent data set; 1981 was a year in which the interregional transfer element in the policy treatment of energy rents was large. The main losers from the removal of federal policies are Atlantic Canada and Quebec, with losses of $24 \%$ and $12 \%$ 
of regional income respectively. Much of the Atlantic Canada loss is attributable to the removal of federal transfers. The overall effect for Canada from the policy change is a gain of $\$ 4.6$ billion or $1.5 \%$ of GNP, in part due to the elimination of the distortionary effects of energy policies. The labour migration effect in case 1 is small, with the net change in population in each region being less than one percent of the region's initial employment. This is due in part to the interregional migration elasticities in the model specification used here.

Removal of all regional policies produces less dramatic results. Atlantic Canada and Quebec both benefit from the change, with gains of $3.4 \%$ and $0.4 \%$ respectively. All other regions lose, with Alberta losing the most at $7 \%$. This loss for Alberta is attributable to the removal of its natural resource based taxes. Overall, Canada suffers a $0.1 \%$ loss in this case. Alberta has a net labour outflow, and labour migrates to all regions except Ontario. The migration flow into Atlantic Canada is due to the removal of significant migration incentives for individuals in Atlantic Canada which arise from the presence of Alberta's resource tax revenues.

Case 3 reports results for the removal of all government policies at both the federal and regional levels (with equal yield tax replacements). Ignoring any interactions between policies across the two levels of government, one might expect the results of case 3 to be approximately equal to the sum of the effects of cases 1 and 2 . The welfare and labour migration results for Alberta are obvious examples of where this does not hold. Table 6 provides results from counterfactual analyses of the regional impacts of separately replacing key federal policies by yield preserving taxes similar to those in Table 5. The regional effects in case 1 reflect the removal of intergovernmental transfers under the equalization programme 
Table 6

Replacement of Specific Federal Policies with an Equal Yield

Federal Sales Tax (Regional Government Policies Constant)

A. Welfare Effects in Terms of Hicksian EV's (\$mill. 1981) 1

Atlantic

Quebec

Ontario

Manitoba/Saskatchewan

Alberta

British Columbia

Total
Case 1 Case 2 Case 3 Case 4

$\begin{array}{cccc}-2004 & -1379 & -231 & -1059 \\ (-9.8) & (-6.7) & (-1.1) & (-5.2) \\ -1345 & -165 & -3421 & -2420 \\ (-1.8) & (-0.2) & (-4.6) & (-3.3) \\ 2151 & -866 & 1132 & -2659 \\ (2.0) & (-0.8) & (1.0) & (-2.4) \\ -378 & -186 & -1215 & 1423 \\ (-1.6) & (-0.8) & (-5.0) & (5.8) \\ 831 & 2038 & 64 & 12228 \\ (2.3) & (5.7) & (0.2) & (34.0) \\ 638 & 335 & 499 & -621 \\ (1.8) & (1.0) & (1.4) & (-1.8) \\ -71 & -192 & -2825 & 6918 \\ (-0.2) & (-0.06) & (-0.89) & (2.17)\end{array}$

B. Interregional Net Labour Flows (measured in $\$$ mill of labour income; + implies net inflow)

Atlantic
Quebec
Ontario
Manitoba/Saskatchewan
Alberta
British Columbia

$\begin{array}{rrrr}-2.1 & -0.6 & -0.8 & -2.0 \\ -2.9 & -0.7 & -3.0 & 3.2 \\ 3.4 & -1.1 & -1.7 & -16.0 \\ -0.5 & -0.3 & -0.6 & 0.7 \\ 1.4 & 2.1 & 0.8 & 22.4 \\ 0.8 & 0.6 & 0.4 & -2.0\end{array}$

Case 1: Removal of Intergovernmental transfers.

Case 2: Removal of Federal Interpersonal transfers.

Case 3: Removal of all Federal non-energy taxes.

Case 4: Removal of all Federal energy taxes and subsidies.

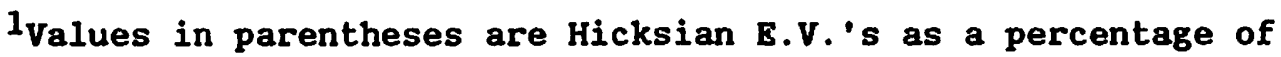
regional income (as a percentage of GNP for the Total). 
and established programes financing. Case 2 is dominated by the removal of federal transfers under unemployment insurance and old age security. Regional results in case 3 mainly reflect the replacement of progressive personal income taxes by a yield preserving proportional sales tax; with losses to lower income regions and gains to higher income regions. The overall loss for Canada in this case is largely attributable to the replacement of federal (non-energy) taxes and the resulting terms of trade deterioration. Results for case 4 reflect the reallocation of benefits between energy producing and energy consuming regions as energy taxes and price controls are removed.

In all these cases the regional impacts of policies are significant, suggesting the value of the type of approach described here. As modelling of this type develops further, many refinements and improvements will no doubt be made. But in raising the level of quantitative input into regional policy debate we hope we have made the potential for this approach clear.

\section{v. CONCLUDING REMARKS}

This paper sumarizes an applied general equilibrium regional model for Canada, constructed to provide a policy appraisal tool for assessing the potential regional impacts of various national and/or regional policy initiatives. The structure of the model is similar to applied models used in other policy areas, such as taxation and international trade, except that special attention has been given to the treatment of interregional factor mobility, the operation of multiple levels of government in the model, and interregional trade and transfers. The model is benchmarked to a 1981 micro consistent regional data set, and results are reported for a series of counterfactual equilibrium analyses which have been performed with the model. While this modelling approach provides a way of assessing regional policy impacts, as one might expect it is not free of problems. Estimates of 
some of the key parameter values, such as interregional elasticity estimates, are sparse. Different treatments of model features (such as interregional factor mobility) could be adopted and many real world complications are missing in the model. Nonetheless, as a method of bridging theory and application we feel the approach has much to commend it. Results are reported for a series of policy simulations which illustrate this. 


\section{vI. BIBLIOGRAPHY}

Armington, P. S. "A Theory of Demand for Products Distinguished by Place of Production." International Monetary Fund Staff Papers XVI (1969): 159-76.

Ballard, C., D. Fullerton, J. Shoven and J. Whalley. General Equilibrium Analysis of U.S. Tax Policy. Chicago: University of Chicago Press for the National Bureau of Economic Research, 1985.

Boadway, R. W. and F. R. Flatters. Equalization in a Federal State: An

Economic Analysis. A study prepared for the Bconomic Council of

Canada. Ottawa: Minster of Supply and Services Canada, 1982.

Caddy, v. "Empirical Estimation of the Elasticity of Substitution: A Review." Industries Assistance Commission, Melbourne, Australia, 1976. (Mimeographed.)

Feldstein, M. and C. Horoika. "Domestic Saving and International Capital Flows." Economic Journal 90 (June 1980): 314-29.

Harberger, A. C. "Vignettes on the World Capital Market." American Bconomic Review 70 (May 1980): 331-37.

Hazledine, T. "The Economic Costs and Benefits of the Canadian Federal Customs Union." In The Political Economy of Confederation. Proceedings of a joint workshop sponsored by the Institute of Intergovernmental Relations (Queen's University), and the Economic Council of Canada. Ottawa: Minster of Supply and Services Canada, 1979.

Kouris, G. "Energy Demand Elasticities in Industrialized Countries: A Survey." A paper drafted on the basis of background material collected for the demand chapter of the World Energy Outlook, IEA, October 1982. 
Mansur, A., and J. Whalley. "Numerical Specification of Applied General Equilibrium Models: Estimation, Calibration and Data." In Applied General Equilibrium Analysis, pp. 69-127. Edited by Herb Scarf and John Shoven. Cambridge: Cambridge University Press, 1984.

Piggott, J. R,. and J. Whalley. Applied General Equilibrium Analysis of U.K. Tax Policy. Cambridge: Cambridge University Press, 1985. St-Hilaire, F., and J. Whalley. "A Microconsistent Equilibrium Data Set for Canada for Use in Tax Policy Analysis." Review of Income and Wealth 29 (June 1983): 175-204.

for Use in Regional General Equilibrium Policy Analysis." Centre for the Study of International Economic Relations, University of Western Ontario, 1985. (Mimeographed.)

Shoven, J. B. and J. Whalley. "Applied General Equilibrium Kodels of Taxation and International Trade." Journal of Economic Literature XXII (September 1984): 1007-51.

Statistics Canada. National Income and Expenditure Accounts, 1968-82.

Cat. No. 13-201. Ottawa: Minister of Supply and Services Canada, 1983a. Statistics Canada. Provincial Economic Accounts, 1966-1981. Cat. No. 13-213. Ottawa: Minister of Supply and Services Canada, 1983b.

Statistics Canada. The Input-output Structure of the Canadian Bconomy, 1971-1980. Cat. No. 12-201E. Ottawa: Minister of Supply and Services Canada, 1984 .

Stern, R. M., J. Francis, and B. Schumacher. Price Elasticities in International Trade: An Annotated Bibliography. London: Macmillan, for the Trade Policy Research Centre, 1976. 
Thirsk, W. R., and R. R. Wright. "The Impact of the Crude Oil subsidy on Economic Efficiency in Canada." Canadian Public Policy 3 (Summer 1977): 355-64.

Whalley, J. Trade Liberalization Among Major World Trading Areas.

Cambridge: MIT Press, 1985.

- and I. Trela. Regional Aspects of Confederation. Volume 68

for the Royal Commission on the Economic Union and Development Prospects

for Canada. Toronto: University of Toronto Press, 1986.

, and B. Yeung. "External Sector 'Closing' Rules in Applied

Equilibrium Models." Journal of International Economics 16 (February 1984): 123-28.

Winer, S., and D. Gauthier. Internal Migration and Fiscal Structure: An Econometric Study of the Determinants of Interprovincial Migration in Canada. Ottawa: Economic Council of Canada, 1982. 


\section{APPEMDIX}

\section{ALGEBRAIC PRESENTATION OF THE STRUCTURE OF THE MODEL}

\section{A. OVERVIEH AND NOTATION}

Canada is modelled as six regions: Atlantic Canada, Quebec, Ontario, Manitoba/Saskatchewan, Alberta, and British Columbia. Regions 1 to 6 refer to the above ordering, with $r$ being the subscript denoting region. Each region contains agents with identical preferences towards goods; agents within a region differing only in their intensity of regional preference.

The federal government is modelled as a separate agent, although it is linked to the regions through its taxes, transfers and expenditures. Federal income accrues from taxation plus ownership of capital. Some of this income is redistributed to regions through intergovernmental transfers and transfers to persons; the remainder is spent on purchases of goods produced by the regions. Federal government activities are subscripted by $G$. The rest of the world is denoted by ROW. The modelling of ROW is essentially the same as for the various Canadian regions, except there are no links to the Canadian federal government through taxes and transfers.

The subscript $j$ refers to industries, while $K, L$ and $N$ refer to the factors capital, labour and natural resources, respectively. Written without a bar, K, L and $N$ indicate use of factors by industries; written with a bar, they denote ownership of factors by region (here region refers to $r=1, \ldots, 6$, and ROW). Thus $k_{j}^{r}$ refers to the use of capital in industry $j$ of region $r$. In this model, the strong assumption has been made that each region owns only the value of factors originally located in that region and appearing in the 
benchnark equilibrium data. $\stackrel{-}{K}^{-r}$ indicates the capital owned by region $r,{ }^{-G}$ denotes the federal government's ownership of capital. Similarly, $\mathbb{N}^{-r}$ denotes ownership of natural resources in region $r$. Since resources are modelled as a factor which is specific to the energy industry in Canada, energy use in region $r$ is simply denoted by $N^{r}$.

Due to the approach to labour mobility modelled here, somewhat different notation is needed for labour inputs. $\stackrel{L}{s}_{s}^{-r}$ is the use of labour in industry $j$ of region $r . L^{-r}$ denotes the supply of labour in region $r, i . e, L^{-r}$ is the initial population of region $r$. After a policy change, labour may have migrated from one region to another; $\stackrel{\mathrm{L}}{s}_{s}^{-r}$ denotes amount of labour of type r locating in region $s$.

$Y$ refers to value added originating in any industry in any region; $G$ refers to the gross output for any industry in any region; $H$ defines the vector of intermediate input requirements for any industry in any region; $X$ is the vector of final purchases (including consumption) by any agent; $U$ is the utility level attained by any agent; and $P$ is a vector of world market prices for both goods and factors. The separate notation for other commodity and factor prices is discussed more fully below.

The solutions of behavioral functions that depend on prices endogenously determined in the model are represented as functions. $X(P)$ are final demands for products as a function of the prices $P . \quad G(P)$ are gross outputs of commodities that meet the vector of final demands $X(P)$ and minimize costs. The basic version of the model incorporates nine factors of production: one labour factor in each region $(r=1, \ldots, 6$, ROW $)$, the internationally and interregionally mobile capital factor, and one resource factor specific to 
Canadian energy industries. Each region produces 13 commodities referred to by the index $i$. The index $j$ refers to industries, 13 in each region. Commodity 13 represents public services and is treated as nontraded. Index $h$ refers to the 91 commodities produced in total.

$a_{h j}^{r}$ indicates the per-unit use of good $h$ in the production of good $j$ in region $r$. $\rho$ denotes substitution parameters on the production side, and $\sigma$ substitution parameters on the demand side. $\stackrel{p}{p}_{j}^{-r}$ determines the elasticity of substitution among components of value added for industry $j$ in region $r$, while $\rho_{j}^{s}$ is used for substitution among intermediate goods in industry $j$ in region s. $\delta$ and $\beta$ are share parameters in the CES functions on the production

side; $b$ are the share parameters in the demand side CES functions.

\section{B. PRICES AND POLICIES IN THE MODEL}

\section{Prices in the Kodel}

The market price for labour in region $r$ is $p_{L}^{r}(r=1, \ldots, 6, R O W)$. In the central case model variant, the market price of capital is $P_{k}$, while in the variant involving international capital immobility, the Canadian market price of capital is $\mathrm{P}_{\mathrm{K}}^{\mathrm{CDN}}$ and the ROW price is $\mathrm{P}_{\mathrm{K}}^{\mathrm{ROW}}$. For the Canadian regions, the natural resource price is $P_{W^{*}}$. These are the prices paid by domestic industries using these factors, net of factor taxes and after receipt of factor subsidies. They are also sellers' prices received by factor owners (before income taxes).

$$
P^{r}=\left(P_{1}^{r}, \ldots, P_{13}^{r}\right) \text { are selling prices for producer outputs in region } r \text {, }
$$
gross of domestic production taxes and subsidies. These are also f.o.b. world export prices received by exporters, and are the before-consumer-purchasetaxes prices paid by domestic consumers for products produced in their 
own region. $P_{h}, P_{1} \ldots P_{91}$ denotes the same producer prices indexed by the goods in all six Canadian regions and ROW.

$P$ is the vector of endogenous model prices $\left(P_{1}, \ldots, P_{91}, P_{K}, P_{Y}, P_{L}^{1}, P_{L}^{2}\right.$, $\cdot P_{L}^{3}, P_{L}^{4}, P_{L}^{5}, P_{L}^{6}, P_{L}^{R O W}$, for the central are variant of the model. For the variant involving international capital immobility, $\hat{p}$ is the vector of endogenous model prices $\left(P_{1}, \ldots, P_{91}, P_{K}^{C D N}, P_{K}^{R O N}, P_{N}, P_{L}^{1}, \ldots, P_{L}^{6}, P_{L}^{R O W}\right)$.

\section{Policies in the Model}

Regional government policy parameters are denoted by the terms $t$ subscripted or superscripted as appropriate, federal government policies denote by the terms $\tau$, again with appropriate subscripts and superscripts.

\section{Trade Policies}

Tariffs are modelled as ad valorem taxes on imports for both intermediate use and final demand. Tariffs imposed by the federal government are on international trade only so that $\boldsymbol{\tau}_{\mathrm{Hh}}^{\mathbf{r}}$ is the federal tariff paid by consumers in region $r$ on international imports of good $h$. Note that this vector of tariff rates is non-zero only for those $h$ values which correspond to imports from ROW. The tariff rates on commodities are uniform across Canadian regions. Because trade barriers between regions are represented as ad valoren equivalent tariffs, $t_{M h}^{r}$ also denotes the tariff imposed by the region $r$ government on imports of good $i$ entering region $r$ from other regions of Canada. $t_{\mathrm{Mh}}^{\text {ROW }}$ are the tariff rates on goods imported by ROW.

\section{Factor Taxes and Subsidies}

Canadian regional governments $(r=1, \ldots, 6)$ impose taxes on labour $t_{L j}^{r}$ 
$(j=1, \ldots, 13)$, on capital $t_{K j}^{r}\left(j \neq\right.$ energy), and on natural resources $t_{\mathbb{N}}^{r}$ used in the energy industry. The federal government similarly imposes taxes ${ }^{r}{ }_{L j}$, $\tau_{K j}^{r}$ and $\tau_{H}^{r}$ on region $r(r=1, \ldots, 6)$. The ROW government imposes ad valorem tax rates $t_{L j}^{R O W}, t_{K j}^{R O W}$ on the use of capital and labour in industry $j$ $(j=1, \ldots, 13)$.

\section{Intermediate Use Taxes and Subsidies}

Each regional government, $r$, imposes ad valorem rates $I_{t_{h j}}$ on the purchase of commodity $h$ for use in industry $j$ in region $r(r=1, \ldots, 6, R O W)$. The federal government imposes similar taxes at rates $I_{\tau_{h j}}$ in regions $r=1, \ldots, 6$

\section{Production Taxes and subsidies}

Each regional government, $r$, uses ad valorem tax rates $t_{P j}^{r}$ on the production of the $j^{\text {th }}$ industry located in region $r(r=1, \ldots, 6$, ROW $)$. Federal government tax rates $t_{P_{j}}$ also apply, with uniform rates across regions.

Consumption Taxes and Subsidies

Each regional government, $r$, uses ad valorem tax rates $t_{i}^{r}$ on the consumption of good $i$ in region. $r(r=1, \ldots, 6$, ROW $)$. Federal government tax rates $\tau_{i}$ also apply.

\section{Income Taxes}

Bach regional government, $r$, applies ad valorem average income tax rates $t_{T}^{r}$ to taxable income of region $r(r=1, \ldots, 6$, ROW $)$. Federal government tax rates $\tau_{T}$ also apply.

\section{PRODUCTION}

\section{Industry Value-Added Functions}

The cEs value-added function for any non-energy industry, $j$, in any region in Canada is 


$$
Y_{j}=r_{j}\left[\delta_{j} \cdot k_{j}^{-p_{j}}+\left(1-\delta_{j}\right) \cdot L_{j}^{-p_{j}}\right]^{-1 / \bar{p}_{j}}, j \neq \text { energy industry }
$$

where $\gamma_{j}$ is a constant defining units of measurement, and $Y_{j}$ is value added in industry $j$. This function also holds for any industry $(j=1, \ldots, 13)$ in ROW. For energy industries in Canada,

$$
Y_{j}=Y_{j}\left[\delta_{j} \cdot N_{j}^{-\rho_{j}}+\left(1-\delta_{j}\right) \cdot L_{j}^{-\rho_{j}}\right]^{-1 / \rho_{j}}, j=\text { energy industry. }
$$

Factor demand functions for an industry reflect cost-minimizing behaviour. Minimizing CES value-added function subject to a given level of output yields the appropriate cost functions.

For a given $P$, factor demands for each non-energy producing industry can be written as:

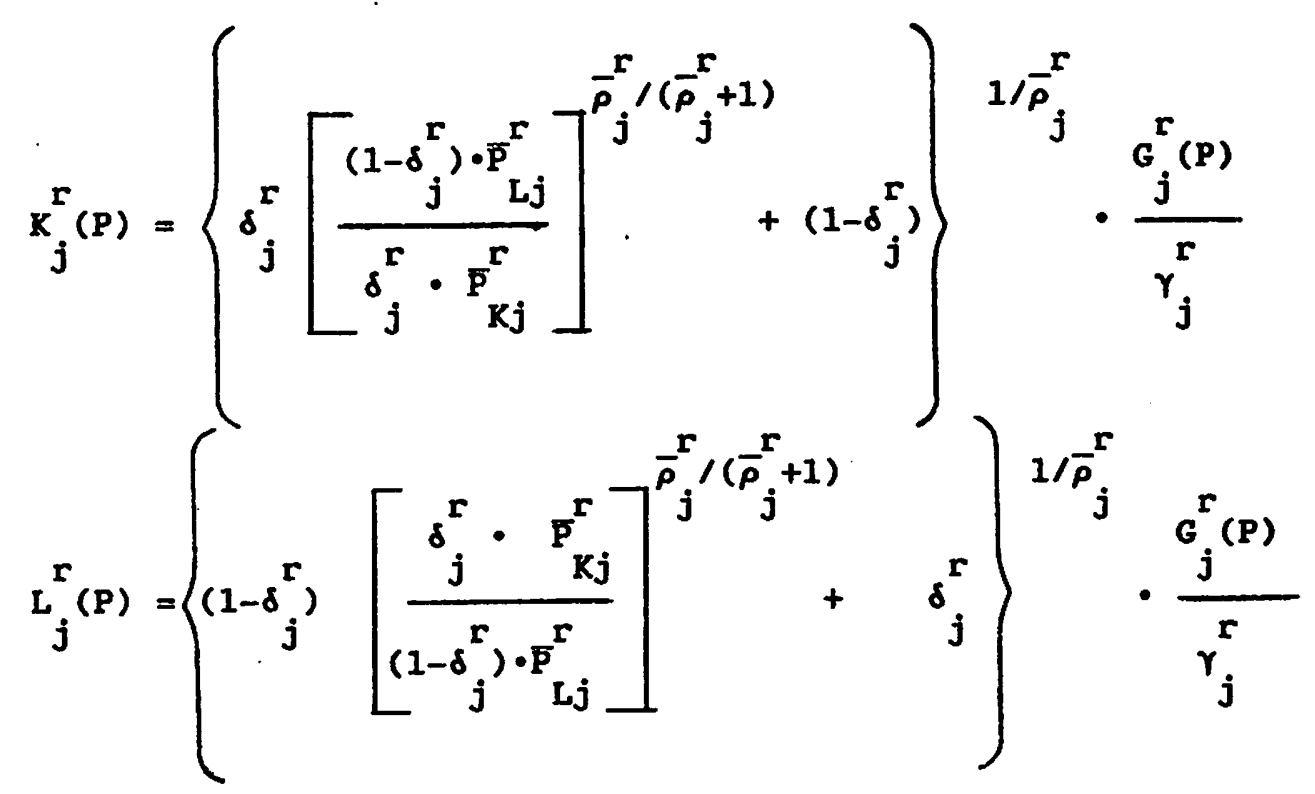

for $r=1, \ldots, 6 ; j \neq$ energy and where 


$$
\begin{aligned}
& \mathrm{P}_{L j}^{-r}=P_{L}^{r} \cdot\left(1+\tau_{L j}^{r}+t_{L j}^{r}\right) \\
& \vec{P}_{K j}^{-r}=P_{K} \cdot\left(1+{ }_{K j}^{r}+t_{K j}^{r}\right)
\end{aligned}
$$

For the energy industry in each region the labour demand equation is identical to that above, while the natural resource factor demands are:

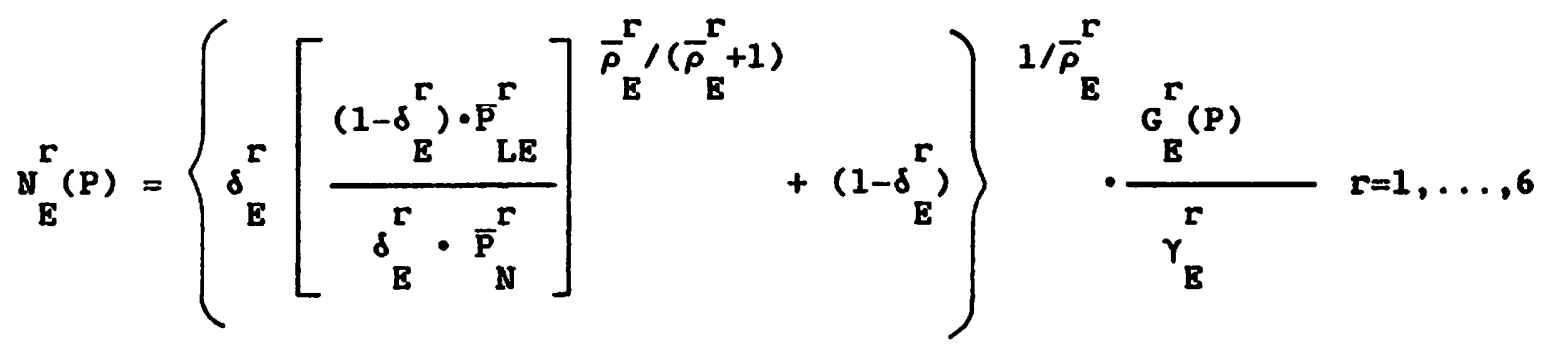

where $\quad{\stackrel{-r}{P_{N}}}^{-r} P_{N} \cdot\left(1+\tau_{N}^{r}+t_{\mathbb{N}}^{r}\right)$

In the ROW, there is no specific resource input to the energy industry and so factor demands for all industries in the ROW are similar to those for Canadian non-energy industries.

Five level nested CES functions are used in calculating intermediate production requirements. As the model structure is different for Row from that for regions in Canada, the regional structure will be described first, beginning with the botton level.

We first consider the use of composites of each of the traded goods (denoted by $\ell=1, \ldots, 12$ ) in industry $j$ in region $s$. The level $5 \mathrm{cEs}$ aggregation function is

Level 5

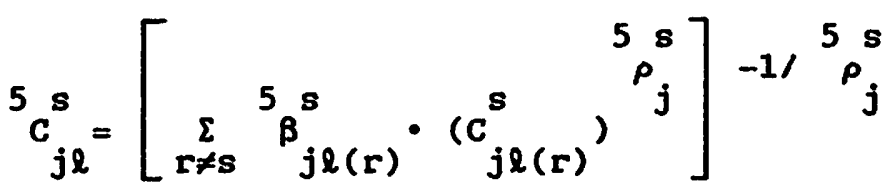


where ${ }^{5} \mathrm{C}_{j \ell}^{\mathrm{s}}$ is the composite of the five types of good $\ell$ produced in regions other than s. The superscript 5 denotes level 5 while the superscript 8 is region $s ; j$ is the industry subscript and $\ell$ the good subscript. $\ell(r)$ denotes good $\ell$ from region $r ; c_{j l(r)}^{s}$ represents the intermediate use by industry $j$ in region $s$ of good $\&$ produced in region $r$. For notational simplicity, the level and region superscripts are dropped from the elasticities and share weights in the functions for subsequent levels.

Level 4

This level describes the substitution between the use of the composite of good $\ell$ available from other regions, ${ }^{5} \mathrm{C}_{j \ell}^{s}$, and the use of the good $\ell$ available from the home region, $c_{j l(s)}^{8} \cdot{ }^{4} c_{j l}^{s}$ is therefore the intermediate use by industry $j$ in region $s$ of the composite of Canadian sources of good 2 .

$$
{ }^{4} c_{j l}^{s}=\left[\beta_{j l}\left(C_{j l}^{s}\right)^{p_{j}}+\left(1-\beta_{j l}\right)\left({ }^{5} c_{j l}^{s}\right)^{p_{j}}\right]^{-1 / p_{j}}
$$

Level 3

Substitution at level 3 occurs between the use of the composite Canadian $\operatorname{good} \ell,{ }^{4} c_{j \ell}^{s}$, and good $\ell$ from ROW, $c_{j \ell(R O W)}^{s}$. This defines ${ }^{3} c_{j \ell}^{s}$, the intermediate use by industry $j$ in region $s$ of the composite good representing all sources of good $\ell .{ }^{3} C_{j \ell}^{s}$ is defined for each of the traded goods, $\ell=1, \ldots, 12$.

$$
\left.{ }_{C_{j l} s}=\left[\beta_{j l}\left(C_{j l}^{s}\right)_{j}^{\rho_{(R O W}}\right)+\left(1-\beta_{j l}\right)\left(C_{j l}^{4}\right)^{\rho_{j}}\right]^{-1 / \rho_{j}}
$$




\section{Level 2}

Substitution at level 2 occurs over the 11 non-energy traded-good composites and the non-traded local public services good for region $s$. The result defines a non-energy composite good.

$$
{ }^{2} c_{j}^{s}=\left[\sum_{i \neq e n e r g y} \beta_{j i}\left({ }^{3} c_{j i}^{s}\right)^{p}\right]^{-1 / p} j
$$

\section{Level 1}

Substitution at level 1 occurs over the non-energy composite good, ${ }^{2} c_{j}^{\mathbf{s}}$, and the energy composite good, ${ }^{3} C_{j E}$, to yield a composite intermediate input for industry $j$ in region $s$.

$$
{ }_{C_{j}} s=\left[\beta_{j}\left(C_{j E}^{3 s}\right)^{p}+\left(1-\beta_{j}\right)\left({ }^{2} c_{j}^{s}\right)^{p} j\right]^{-1 / p_{j}}
$$

The nesting structure used in the model to represent the ROW differs from the structure above only for levels 3 to 5 , where substitution across goods produced in other regions occurs. For level 5 , goods produced in all Canadian regions appear, i.e.

$$
{ }_{C_{j l}^{\text {ROW }}}=\left[\sum_{r=1}^{6} \beta_{j \ell(r)}^{\text {ROW }}\left(C_{j \ell(r)}^{\text {ROW }}\right)^{p}\right]^{-1 / p_{j}} \quad \ell=1, \ldots, 12
$$

and the level 4 substitution does not apply for ROW. Level 3 substitution involves the Canadian composite and the good produced in Row. This yields 12 traded-good composites, i.e.

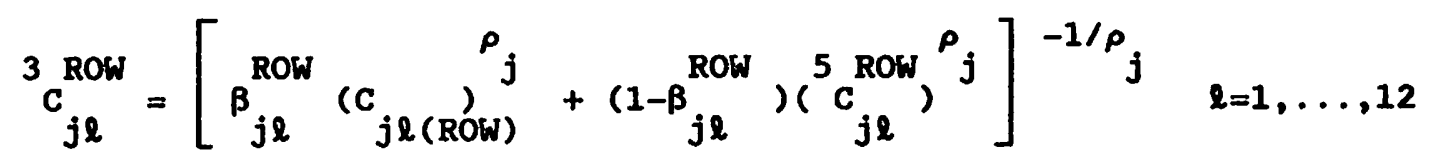


The next two levels are the same as for the Canadian regions.

\section{Industry Production Levels to Heet Consumer Demands}

Intermediate demand functions reflect cost-minimizing behaviour. Cost minimizing subject to the the CES intermediate requirement functions at each nesting level yields the appropriate cost functions; for space reasons the derivation of these functions is not reproduced here. The cost functions for ROW industries differ from those of Canadian industries. The nesting structure at the first level is, however, the same for all industries over all regions and will be used to illustrate the basic structure.

Expenditure on intermediate goods by industry $j$ in region $r$ is denoted by $\mathbf{H}_{j}^{r}$, where

$$
\mathbf{H}_{j}^{\mathbf{r}}=\mathrm{PD}_{\mathbf{j}}^{\mathbf{r}} \cdot{ }^{1} \mathrm{C}_{\mathbf{j}}^{\mathbf{r}} \text {. }
$$

${ }^{1} c_{j}$ is the quantity of the intermediate use composite good at level 1 of the nesting structure, while $\mathrm{PD}_{j}^{\mathbf{r}}$ denotes the price of this composite good.

The CES intermediate requirement subfunction underlying ${ }^{1} c_{j}$ at level 1 yields the intermediate demand functions for the energy and non-energy composites, i.e. the demand function for the non-energy composite in industry $j$ in region $r$ is

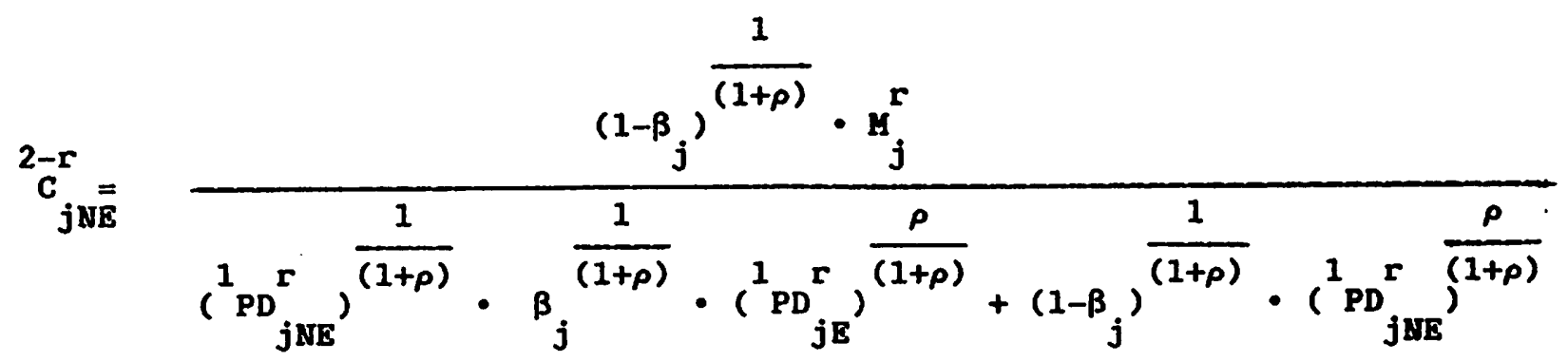

where the superscripts which denote level 1 and region $r$ for the $\beta$ 's and $\rho$ have been supressed for simplicity of exposition. Defining the term in the 
square brackets in the equation above as ${ }^{1} \mathrm{Ps}_{j}^{r}$, then

$$
P D_{j}^{r}=\left(\operatorname{PS}_{j}\right)^{\frac{1}{(1+\rho)}}
$$

defines the price index for the composite good ${ }^{1} c_{j}^{r}$. similarly, the price indexes ${ }^{1}{ }_{P D}^{r}{ }_{j N E}^{r}$ and ${ }^{1}{ }_{P D}^{r}$ are calculated using parameters from the lower levels of the intermediate requirement functions.

The CES subfunction for ${ }^{2} c_{j}^{r}$ at level 2 yields the intermediate demand functions for each of the 11 non-energy traded good composites and for the public services good in $r$. Similarly, the appropriate demand functions are derived for each of the lower levels. At these lower levels, the price indexes are calculated from the domestic (gross of tax) prices of the individual goods, i.e.

$$
\bar{P}_{h j}^{-r}=P_{h} \cdot\left(1+\tau_{M h}^{r}+t_{M h}^{r}+T_{h j}^{r}+I_{h j}^{r}\right)
$$

is the price that industry $j$ in region $r$ pays for good $h(h=1, \ldots, 91)$.

The result of this cost-minimizing process is to yield the per-unit requirements $a_{h j}^{r}$, i.e. the per-unit requirement of good $h$ in the production of good $j$ in region $r$. Given $X(P)$, the vector of $f$ inal demands for goods as a function of $P$, and $A(P)$, the matrix of elements $a_{h j}^{r}$, then

$$
G(P)=[I-A(P)]^{-1} X(P)
$$

yields the gross output of commodities that meets the vector of final demands and minimizes intermediate production costs. 


\section{CONSUAPTION}

Demands for all agents in the model are based on utility-maximizing behaviour subject to agent budget constraints, with nested CES utility functions used to represent agent preferences. The five level nesting structure for Canadian agents is identical to that used to represent Canadian intermediate requirements in production. At the top level, agent utility is a function of an energy and a non-energy composite, both of which are defined by the nesting structure used for the lower levels. Similarly, final demand preferences in ROW follow the ROW intermediate requirement nesting structure. The federal government is modelled as a utility-maximizing agent and the preference structure used is similar to that for ROW.

\section{Agent Budget Constraints}

\section{Regions}

The budget constraint for each region defines regional income $\mathrm{I}^{\mathbf{r}}$, where

$$
I^{r}=P_{K} \cdot \bar{K}^{-r}+P_{L}^{r} \cdot L^{-r}+T^{r}+R^{r}-I T^{r}
$$

and $P_{K}$ is the world price of capital, $P_{L}^{r}$ is the wage received by labour in region $r, T R$ defines the federal government transfers to $r, R^{r}$ is regional government net tax revenues (assumed redistributed in lump-sum form), and IT $^{r}$ defines federal personal income taxes paid in $r$.

\section{Federel Government}

The federal government budget constraint is represented by income $I^{G}$, where

$$
I^{G}=P_{k} \cdot \bar{K}^{-G}+R^{G}-\sum_{r=1}^{G} T R^{r}
$$


and $\ddot{K}$ is federal ownership of capital and $R^{G}$ is federal net tax revenue.

ROW

The budget constraint for the foreign agent, ROW, is given by the income term $I^{\text {ROW }}$ where

$$
\mathrm{I}^{\mathrm{ROW}}=\mathrm{P}_{\mathrm{k}} \cdot \mathrm{K}^{-\mathrm{ROW}}+\mathrm{P}_{\mathrm{L}}^{\mathrm{ROW}} \cdot \mathrm{R}^{\mathrm{ROW}} \cdot
$$

\section{Final Demands}

The total final demand for any $\operatorname{good}$ is $x_{h}=\sum_{r} x_{h}^{r}$, where $h=1, \ldots, 91$

and $r$ refers to all 6 regions in Canada, ROW, and G. Maximizing the CES utility subfunctions at each level of the nesting structure yields the final demand functions for the composite goods, and at the lower levels the final demand functions for the individual goods. Since the nesting structure is the same as that used for the intermediate requirement functions in production, the derived final demand functions also have the same form as the intermediate demand functions.

Price indexes of the composites used in the functions are derived from the consumer prices of the individual goods. Consumer prices in each region $r$ in Canada are denoted by

$$
\vec{P}_{h}^{-r}=P_{h} \cdot\left(1+\tau_{M h}^{r}+t_{M h}^{r}+T_{h}^{r}+t_{h}^{r}\right) \quad r=1, \ldots, 6 ; h=1, \ldots, 91
$$

The federal government pays no taxes and so 


$$
P_{h}^{-G}=P_{h} \quad h=1, \ldots, 91
$$

and for Row

$$
\bar{P}_{h}^{- \text {ROW }}=P_{h} \cdot\left(1+t_{\text {Mh }}^{\text {ROW }}+t_{h}^{\text {ROW }}\right) \text {. }
$$

\section{B. TRRATIERIT OF FACTOR GOBILITY}

The resource factor is specific to both Canada and the energy industry, so it is internationally and intersectorally immobile. Accordingly, the Canadian price for the energy factor is $P_{N}$, with the energy industry in a region $r$ facing the price

$$
\vec{P}_{N}^{-r}=P_{N} \cdot\left(1+t_{N}^{r}+t_{N}^{r}\right)
$$

Two versions of the model with different treatments of capital mobility are used. In the basic model variant, capital is intersectorally, interregionally, and internationally mobile. In this case there exists a single world price for capital. The other model variant has capital as intersectorally and interregionally mobile, but not internationally mobile. The price of capital faced by a Canadian region in this variant is

$$
\vec{P}_{K j}^{-r}=P_{K}^{C D N} \cdot\left(1+\tau_{K j}^{r}+t_{K j}^{r}, \quad r=1, \ldots, 6 ; j \neq\right. \text { fenergy, }
$$

and for the ROW is

$$
\mathrm{P}_{\mathrm{Kj}}^{\mathrm{ROW}}=\mathrm{P}_{\mathrm{K}}^{\mathrm{ROW}} \cdot\left(1+\mathrm{t}_{\mathrm{Kj}}^{\mathrm{ROW}}\right) \quad j=1, \ldots, 13 .
$$

A further modification is necessary for this variant in the statement of the model equilibrium conditions. 
A feature of the model which differentiates it from other applied general equilibrium models is the treatment of partial labour mobility between regions. Labour is assumed to be homogeneous across all regions in Canada in all respects but one: Labour originally located within a region is assumed to have a preference for residing in that region over any other. These locational preferences are represented by a penalty which is incurred if the home region is left. The size of the penality, i.e., the strength of locational preference, is assumed to vary systematically over the individuals intially located within a region. $\mu^{r}$ is the parameter of intensity of locational preference in region $r$, and $m_{i}^{r}=\left(\mu^{r} \cdot i\right)$ is the penalty to individual $i$ in $r$ on leaving.

The analysis in the test of the paper describes the labour migration decision process in terms of utility maximization with utility penalties on relocation. Strong assumptions, which are discussed later, are employed here and allow the modelling of partial labour mobility to be based directly on relative income differences rather than on differences in utility. $\mu^{r}$ is thus a measure of locational preference in terms of income, while $\mathrm{m}_{i}^{r}$ is the income penalty incurred to individual $i$ in region $r$ on leaving.

Units of labour in each region are defined in terms of the amount of labour which earns one dollar worth of income in the benchmark equilibrium data. There are thus ${ }^{-r}$ units of labour in each region $r$. The income that enters this measure and affects migration decisions is 1

\footnotetext{
1 -r
}

Individuals are indexed from 0 to $\left(\mathrm{L}^{-1}-1\right)$ to accomodate the assumption of individual 0 as the marginal labour unit. 


$$
\vec{I}_{i}^{-r}=P_{L}^{r}+\frac{T R^{r}}{-r}+\frac{R_{N}^{r}}{-r}, \quad i=0, \ldots,\left(L^{-r}-1\right)
$$

where $R_{W}^{r}$ is natural resource tax revenues of the regional government, and $T^{r}$ is transfers received by region $r$ from the federal government. Individuals in a region are assumed identical in terms of per capita income. Based on differences between this and similar measures for per capita income in other regions, and the strength of locational preferences, individuals in region $r$ decide whether or not they should migrate.

For notational ease, the discussion which follows will drop the home region subscript, $r$. The analysis applies to any Canadian region, and $s$ is used to refer to all other Canadian regions.

The per capita income measure for an outside region $s$ which an individual $i$ contemplates moving to is

$$
\bar{I}_{i}^{-S}=P_{L}^{S}+\frac{T R}{-S}+\frac{R_{N}^{S}}{-S}
$$

For tractability of the modelling treatment, a fixed coefficient composite of outside income is used in the migration decision, calculated as

$$
\bar{I}_{i}^{F}=\sum_{s \neq r} \alpha^{s} \bar{I}_{i}^{s}
$$

and each individual $i$ within the region uses this value in making his migration decision. If the horne per capita income is $\bar{I}_{i}^{-H}$, then the labour 
migration decision is assuned to be a function of $I_{i}^{H}, I_{i}^{F}$ and $\mu$. For the initial benchmark situation, the first individual in a region is the marginal individual, i.e. the individual on the margin between leaving the region and remaining. We index this individual as $i=0$, so that for this value of $i$, $m_{i}=\mu \cdot i=0$, hence

$$
\overline{\mathrm{I}}_{0}^{-\mathrm{F}}=\stackrel{-\mathrm{H}}{\mathrm{I}}_{0}^{-\mathrm{H}}
$$

All other individuals suffer a penalty on leaving the region, and since their out-of-home-region income net of penalties is less than that of individual 0 , they choose to remain in the home region. This net of penalty income is calculated as

$$
\stackrel{i}{F}_{i}^{F}=\bar{I}_{0}^{-F}-(\mu \cdot i)
$$

If, however, a change in policies occurs, and net outside income increases, i.e. $\bar{I}_{0}^{-F}>I_{0}^{-H}$, then the outmigration will occur up to the point where $I_{0}^{H}={ }^{a} I_{k}$, where $k$ will now represent the marginal individual. The number of individual migrating can then be calculated from

$$
\vec{I}_{0}^{-H}=\frac{-F}{I_{0}}-(\mu \cdot i)
$$

as

$$
i=\left(\bar{I}_{0}^{-F}-\bar{I}_{0}^{-H}\right) / \mu
$$


The individuals leaving a region are assumed to distribute themselves over outside regions using the same fixed coefficient approach by which the composite outside region income is determined. This, migration to region s from the home region being considered here is given by $x^{8}=\alpha^{3} \cdot i$, where $i$ is the outmigration determined above. The total inmigration to region $s$ is given by the sum across all outmigrating regions of the amount of labour entering region s.

The series of strong assumptions which underlie the treatment employed here to model partial labour mobility should be highlighted. One is that any individual leaving region $r$ for region $s$ retains the preferences he originally had in region $r$. Furthermore, the individual is assumed to still face region $r$ prices. Finally, any migrating individual's income is assumed to change only in those components which make up the migration decision income measure.

\section{F. MODEL EQUILIBRIUY CONDITIONS}

Equilibrium in the model is characterized by a series of conditions:

\section{(i) Demand-Supply Equalities for Comodities and Factors}

- for all comonodities

$X_{h}(P)=G_{h}(P)-\sum_{r=1}^{6, R O W} \sum_{j=1}^{13} a_{h j}^{r} G_{j}^{r}(P) \quad h=1, \ldots, 91$

- for capital

- (in basic model variant)

$\underset{r=1}{6, \text { ROW }} \underset{j=1}{\sum_{j=1}^{13}} K_{j}^{r}(P)=\underset{r=1}{6, \text { ROW }, G} \mathbb{R}^{r}$ 
- (in the international immobility variant)

$$
\begin{aligned}
& \sum_{j=1}^{\sum_{1}} K_{j}^{\text {ROW }}(\hat{P})=K^{- \text {ROW }} \\
& 613 r \cdot 6, G-r \\
& r=1 \quad \sum_{j} K_{j}(P)=\sum_{=1}^{\Sigma_{1}} K \\
& \text { - for 1 abour } \\
& \sum_{j=1}^{13} L_{j}^{\text {ROW }}(P)=t^{\text {ROW }} \\
& \sum_{j=1}^{13} L_{j}^{r}(P)=E^{r} \quad r=1, \ldots, 6
\end{aligned}
$$

where after migration has occurred, $\bar{L}^{r}=\bar{L}_{r}^{r}+\sum_{s \neq r} \bar{L}_{s}^{r} \cdot \bar{L}_{r}^{r}$ is the number of original individuals in $r$ who remain in $r ; \mathrm{L}_{\mathrm{s}}^{-\mathrm{r}}$ is the number of individuals from region $s$ who migrate to $r$.

- Eor ñatural r resourrẹ

$$
\sum_{r=1}^{6} N^{r}(P)=\sum_{r=1}^{6} N^{-r}
$$

\section{(ii) Zero Profit Conditions for Industries (Basic Model Variant)}

$$
\begin{aligned}
& P_{(j, r)}=\left(1+\tau_{P j}+t_{P j}^{r}\right) \quad\left[\bar{P}_{K}^{r} \cdot \frac{K_{j}^{r}(P)}{G_{j}^{r}(P)}+\bar{P}_{L}^{r} \cdot \frac{{ }_{j}^{r}(P)}{G_{j}^{r}(P)}\right. \\
& \text { (Domestic factor costs) } \\
& \left.+\sum_{k=1}^{13} \sum_{s=1}^{6, \text { ROW }} a_{(k, s) j}^{r} \cdot P_{(k, s) j}^{-r}\right]
\end{aligned}
$$


(Costs of intermediate use of domestic products and exports) The producer price for industry $j$ in region $r$ (where the subscript $(j, r)$ denotes the $h$ value corresponding to $j$ and $r$ ) covers production costs, including domestic production taxes and subsidies. Note that for ROW, ${ }^{T_{P j}}$ is zero.

(iii) Trade Balance (Basic Model Variant)

- EOE ROW

$\sum_{r=1}^{6, G} \sum_{i=1}^{13} P_{(i, R O W)} \cdot x_{(i, R O W)}^{r}(P)=\sum_{r=1}^{6} \sum_{i=1}^{13} P_{(i, r)} \cdot x_{(i, r)}^{R O W}(P)$

(Value of merchandise exports) (Value of merchandise imports)

$$
+P_{K} \cdot\left(\sum_{j=1}^{13} K_{j}^{\text {ROW }}-\bar{K}^{- \text {ROW }}\right)
$$

(net capital imports from abroad)

- for each_Canadian region. $\underline{S}$

$$
\begin{aligned}
\sum_{r \neq s} \sum_{i=1}^{13} P(i, s) \cdot X_{(i, s)}^{r}(P)+T^{s} & =\sum_{r \neq s} \sum_{i=1}^{13} P(i, r) \cdot X_{(i, r)}^{s}(P) \\
& +P P_{K} \cdot\left(\sum_{j=1}^{13} K_{j}^{s}-\bar{K}^{-s}\right)
\end{aligned}
$$

- for the Federal Government

$$
I^{G}=R^{G}+P_{X} \cdot R^{G}-\sum_{r=1}^{6} T R^{r}=\sum_{h=1}^{91} P_{h} \cdot X_{h}^{G}(P)
$$


8401C Harrison, Glenn $W$. and Manning, Richard. BEST APPROXIMATE AGGREGTION OF INPUT-OUTPUT SYSTEMS.

8402C Parkin, Michael. CORE INFLATION: A REVIEW ESSAY.

8403C Blomqvist, $\dot{C}$ ike, and McMahon, Gary. SIMULATING COMMERICAL POLICY IN A SMALL, OPEN DUAL ECONOMY WITH URBAN UNEMPLOYMENT: A GENERAL EQUILIBRIUM APPROACH.

$8404 \mathrm{C}$ Wonnacott, Ronald. THE THEORY OF TRADE DISCRIMINATION: THE MIRROR IMAGE OF VINERIAN PREFERENCE THEORY?

8405C Whalley, John. IMPACTS OF A 50\% TARIFF REDUCTION IN AN EIGHT-REGION GLOBAL TRADE MODEL.

8406C Harrison, Glenn W. A GENERAL EQUILIBRIUM ANALYSIS OF TARIFT REDUCTIONS.

8407C Horstmann, Ignatius and Markusen, James R. STRATEGIC INVESTMENTS AND THE DEVELOPMENT OF MULTINATIONALS.

8408C Gregory, Allan $W$. and McCurdy, Thomas H. TESTING THE UNBIASEDNESS HYPOTHESIS IN THE FORINARD FOREIGN EXCHANGE MARKET: A SPECIFICATION ANALYSIS.

8409C Jones, Ronald $\mathrm{H}$. and Klerzkowsk1, Henryk. NEIGHBORHOOD PRODUCTION STRUCTURES WITH APPLICATIONS TO THE THEORY OF INTERNATIONAL TRADE.

$8410 \mathrm{C}$ Weller, Paul and Yano, Makoto. THE ROLE OF FUTURES MARKETS IN INTERNATIONAL TRADE: A GENERAL EỌUILIBRIUM APPROACH.

$8411 \mathrm{C}$ Brecher, Richard A, and Bhagwat1, Jagdish N. VOLUNTARY EXPORT RESTRICTIONS VERSUS IMPORT RESTRICTIONS: A WELFARE-THEORETIC COMPARISON.

$8412 \mathrm{C}$ Ethier, W11fred J. ILLEGAL IMMICRATION.

8413C Eaton, Jonathon and Gene M. Grossman. OPTIMAL TRADE AND INDUSTRIAL POLICY UNDER OLIGOPOLY.

8414C Hooton, Ian. PREFERENTIAL TRADING AGREEMENTS - A $3 \times n$ MODEL.

8415C Parkin, Michael. DISCRIMINATING BETWEEN KEYNESIAN AND CLASSICAL THEORIES OF THE BUSINESS CXCLE; JAPAN $1967-1282$

8416C Deardorff, Alan V. FIRless FIRwoes: HOW PREFERENCES CAN INTERFERE WITH THIE THEOREYS OF INTERNATIONAL TRADE.

3417C Greenwood, Jeremy. NONTRADED GOODS, THE TRADE BALANCE, AND THE BALANCE OF PAYNENTS. 
8418C Blomqvist, Ake and Sharif Mohammad. CONTROLS; CORRUPTION, AND COMPETITIVE RENT-SEEKING IN LDCS.

8419C Grossman, Herschel I. POLICY, RATIONAL EXPECTATIONS, AND

$8420 \mathrm{C}$

Garber, Peter M. and Robert G. King. DEEP STRUCTURAL EXCAVATION? A CRITIOUUE OF EULER EQUATION METHODS.

Barro, Robert J. THE BEHAVIOR OF U.S. DEFICITS.

8422C Persson, Torsten and Lars E.0. Svensson. INTERNATIONAL BORROWING AND TIME-CONSISTENT FISCAL POLICY.

8423C Obstfeld Maurice. CAPITAL CONTROLS, THE DUAL EXCHANGE RATE, AND DEVALUATION.

8424C Kuhn, Peter. UNION PRODUCTIVITY EFFECTS AND ECONOMIC EFFICIENCY.

8425C Hamilton, Bob and John Whalley. TAX TREATMENT OF HOUSING IN A DYNAMIC SEOUUENCED GENERAL EOUUILIBRIUM MODEL.

Hamilton, Bob, Sharif Mohammad, and John Whalley. RENT SEEKING AND THE NORTH-SOUTH TERMS OF TRADE.

Adams, Charles and Jeremy Greenwood. DUAL EXCHANGE RATE SYSTEMS AND CAPITAL CONTROLS: $\Lambda$ N INVESTIGATION.

Loh, Choon Cheong and Michael R. Veall. A NOTE ON SOCIAL SECURITY AID PRIVATE SAVINGS IN SINGAPORE.

8429 Whalley, John. REGRESSION OR PROGRESSION: THE TAXING OUESTION OF INCIDENCE ANALYSIS.

3430 Kuhn, Peter. WAGES, EFFORT, AND INCENTIVE-COMPATIBILITY IN LIFE-CYCLE EMPLOYMENT CONTRACTS.

\$431 Greenwood, Jereny and Kent P. Kimbrough. AN INVESTIGATION IN THE THEORY OF FOREITN EXCHANGE CONTROLS.

Creenwood, Jeremy and Kent P. Kimbrough. CAPITAL CONTROLS AND THE INTERNATIONAL TRANSMISSION OF FISCAL POLICY. 8433 Nguyen, Trien Trien and John Whalley. EỌUILIBRIUM UNDER
PRICE CONTROLS WITH ENDOGENOUS TRANSACTIONS COSTS.

8434 Adams, Charles and Russell S. Boyer. EFFICIENCY AND A SIMPLE MODEL OF EXCHANCE RATE DETERMINATION. 
8435 Kuhn, Peter. UNIONS, ENTREPRENEURSHIP, AND EFFICIENCY.

8436 Hercowttz, Zv1 and Efraim Sadka. ON OPTIMAL CURRENCY. SUBSTITUTION POLICY AND PUBLIC PINANCE.

8437 Lenjosek, Gordon and John Whalley. POLICY EVALUATION IN A SMALL OPEN PRICE TAKING ECONOMY: CANADIAN ENERGY POLICIES.

8438 Aschauer, David and Jeremy Greenwood. MACROECONOMIC EFFECTS OF FISCAL POLICY.

8439C Hercowitz, ZVI. ON THE DETERMINATION OF THE EXTERNAL DEBT: THE CASE OF ISRAEL.

8440C Stern, Robert M. GLOBAL DIMENSIONS AND DETERMINANTS OF INTERNATIONAL TRADE AND INVESTMENT IN SERVICES.

844 IC Deardorff, Alan V. COMPARATIVE ADVANTAGE AND INTERNATIONAL TRADE AND INVESTMENT IN SERVICES.

8442C Daly, Donald J. TECHNOLOGY TRANSFER AND CANADA'S COMPETITIVE PERFORMANCE.

8443C Grey, Rodney de C. NEGOTIATING ABOUT TRADE AND INVESTMENT IN SERVICES.

8444C Grossman, Gene M. and Carl Shapiro. NORMATIVE ISSUES RAISED BY INTERNATIONAL TRADE IN TECHNOLOGY SERVICES.

3445C Chant, John $F$. THE CANADIAN TREATMENT OF FOREIGN BANKS: A CASE STUDY IN THE WORKINGS OF THE NATIONAL TREATMENT APPROACH. Aronson, Jonathan $D$. and Peter F. Cowhey. COMPUTER, DATA $8446 C$ Aronson, Jonathan D. and Peter F. Cowhey
PROCESSING, AND COMMUICATION SERVICES.

8447C Feketkkuty, Geza. NEGOTIATING SIRATEGIES FOR LIBERALIZING TRADE AND INVESTMENT IN SERVICES.

8448C Harrison, Glenn, W. and E.E. Rutstrom. THE EFFECT OF MANUFACTURING SECTOR PROTECTION ON ASEAN AND AUSTRALIA: A GENERAL ENUILIBRIUM ANALYSIS. 
8501C Greenwood, Jeremy and Kent P. Kimbrough. FOREIGN EXCHANGE CONTROLS IN A BLACK MARKET ECONOMY.

8502C Horstmann, Ignatius and James R. Markusen. UP YOUR AVERAGE COST CURVE: INEFFICIENT ENTRY AND THE NEW PROTECTIONISM.

8503C Gregory, Allan $\mathrm{W}$. TESTING INTEREST RATE PARITY AND RATIONAL EXPECTATIONS FOR CANADA AND THE UNITED STATES.

8504C Kuhn, Peter and Ian Hooton. INTERNATIONAL FACTOR MOVEMENTS IN THE PRESENCE OF A FIXED FACTOR.

8505C Wong, Kar-yIu. GAINS FROM GOODS TRADE AND RACTOR MOBILITY.

8506C Weller, Paul and Makoto Yano. FUTURES MARKETS, REAL INCOME, AND SPOT PRICE VARIABILITY: A GENERAL EOUUIIBRIUM APPROACH.

8507C Diewert, H.E. THE EFFECTS OF AN INNOVATION: A TRADE THEORY APPROACH.

8508C Ethier, Wilfred J. FOREIGN DIRECT INVESTMENT AND THE MULTINATIONAL FIRM.

8509C Dinopoulos, Elias. INSIDE THE BLACK BOX: (IN)TANGIBLE ASSETS, INTRA-INDUSTRY INVESTMENT AND TRADE.

8510C Jones, Richard, John Whalley, and Randall Higle. REGIONAL IMPACTS OF TARIFFS IN CANADA: PRELIMINARY RESULTS FROM A SMALL DIMENSIONAL NUMERICAL GENERAL EOUUILIBRIUM MODEL.

8511C Whalley, John. HIDDEN CHALLENGES IN RECENT APPLIED GENERAL EQUUIL IBRIUM EXERCISES.

8512C Smith, Bruce. SOME COLONIAL EVIDENCE ON TWO THEORIES OF MONEY: MARYLAND AND THE CAROLINAS.

3513C Grossman, S.J., A. Melino, and R.J. Shiller. ESTIMATING THE CONTINUOUS TIME CONSUMPTION BASED ASSET PRICING MODEL.

8514C Romer, Paul R. TAX EFFECTS AND TRANSACTION COSTS FOR SHORT TERM MARKET DISCOUNT BONDS.

8515C McCallum, Bennett T. ON CONSEOUUENCES AND CRITJCISMS OF MONETARY TARGETING.

8516C Dinopoulos, Ellas and Ian Wooton. A NORTH-SOUTH MODEL OF INTERNATIONAL JUSTICE.

8517C Huffman, Gregory W. A DYNAMIC EQUILIBRIUM MODEL OF ASSET PRICES AND TRANSACTION VOLUME.

8518C Huffman, Gregory W. AN ALTERNATIVE VIEW OF OPTIMAL SEIGNIORAGE.

8519C Huffman, Gregory W. ASSET PRICING WITH HETERGENEOUS ASSETS. 
8520C Hercowitz, Zvi. THE REAL INTEREST RATE AND AGGREGATE SUPPLY.

8521C Davies, James and Michael Hoy. COMPARING INCOME DISTRIBUTIONS UNDER AVERSION TO DOWNSIDE INEQUALITY.

8522C Nguyen, Trien $T$. and John Whalley. COEXISTENCE OF EQUIIIBRIA ON BLACK AND WHITE MARKETS.

$8523 \mathrm{C}$ Clarece, Ramon and John Whalley. INTERACTIONS BETWEEN TRADE POLICIES AND DOMESTIC DISTORTIONS: THE PHILIPPINE CASE.

8524C Hamilton, Bob, Sharif Mohammad, and John Whalley. APPLIED GENERAL EQZUILIBRIUM ANALYSIS AND PERSPECTIVES ON GROWTH PERFORMANCE.

8525C Huffman, Gregory $W$. THE LAGGED EFFECTS OF POLICY ON THE PRICE LEVEL.

8526C Laldler, David. FISCAL DEFICITS AND INTERNATIONAL MONETARY INSTITUTIONS.

8527C Goodfriend, Marvin. MONETARY MYSTIQUE: SECRECY AND CENTRAL BANKING.

8528C Nguyen, Trien $T$. and. John Whalley. GENERAL EQUILIBRIUM ANALYSIS OF PRICE CONTROLS A TWO-SECTOR COMPUTATIONAL APPROACH.

8529C Heckman, James J. and V. Joseph Hotz. AN INVESTIGATION OF THE LABOR MARKET EARNINGS OF PANAMANIAN MALES: EVALUATING SOURCES OF INEQUALITY.

8530C Greenwood, Jeremy and Gregory W. Huffman. A DYNAMIC EQUIIIBRIUM MODEL OF INFLATION AND UNEMPLOYMENT.

8531C Freeman, Scott. INSIDE MONEY, MONETARY CONTRACTIONS, AND WELFARE.

8532C Paderanga, Cayetano Jr. and Ian Wooton. A POSITIVE VIEW OF INFANT INDUSTRIES.

8533C St-Hilaire, France and John Whalley. A MICROCONSISTENT DATA SET FOR CANADA FOR USE IN REGIONAL GENERAL EQUILIBRIUM POLICY ANALYSIS.

8534C Whalley, John. OPERATIONALIZING WALRAS: EXPERIENCE WITH RECENT APPLIED GENERAL EQUILIBRIUM TAX MODELS.

8535C Melvin, James R. THE GENERAL NON-EQUIVALENCE OF. TARIFFS AND IMPORT QUOTAS. 
8601C Greenwood, Jeremy and R. Preston McAfee. EXTERNALITIES AND ASYMMETRIC INFORMATION.

8602C Dinopoulos, Elias and Mordecha1 E. Kreinin. IMPORT QUOTAS AND VERS: A COMPARATIVE ANALYSIS IN A THREE-COUNTRY FRAMEWORK.

$8603 \mathrm{C}$ Clarete, Ramon and John Whalley. COMPARING THE MARGINAL WELFARE COSTS OF COMMODITY AND TRADE TAXES.

8604C Wigle, Randy. CANADIAN TRADE LIBERALIZATION: SCALE ECONOHIES IN A GLOBAL CONTEXT.

8605C Parkin, Michael. DOMESTIC MONETARY INSTITUTIONS AND FISCAL DEFICITS.

8606C Dinopoulos, Elias and Ian Wooton. INTERNATIONAL TRADE AND THE ACQUISITION OF SKILLS.

8607C Kawasaki, Seilchi and John McMillan. THE DESIGN OF CONTRACTS: EVIDENCE FROM JAPANESE SUBCONTRACTING.

8608C Williamson, Stephen D. LIQUIDITY, BANKING, AND BANK FAILURES.

8609C Grossman, Gene M. and Carl Shapiro. COUNTERFEIT-PRODUCT TRADE.

8610C Deardorff, Alan $\mathrm{V}$. WHY DO GOVERNMENTS PREFER NONTARIFF BARRIERS?

8611C Horstmann, Ignatius and James R. Markusen. LICENS ING VERSUS DIRECT INVESTMENT: A MODEL OF INTERNALIZATION BY THE MULTINATIONAL ENTERPRISE.

8612C Thursby, Jerry G. and Marie C. Thursby. BILATERAL TRADE FLOWS, THE LINDER HYPOTHESIS, AND EXCHANGE RISK.

8613C Clarete, Ramon and John Whalley. EQUIIIBRIUM IN THE PRESENCE OF FOREIGN EXCHANGE PREMIA.

8614C Wooton, Ian. TOWARDS A COMMON MARKET: FACTOR MOBILITY IN A CUSTOMS UNION.

8615C St-Hilaire, France and John Whalley. SOME ESTIMATES OF TRADE FLOWS IN BANKING SERVICES.

8616C Evenson, Robert E. and Cayetano Paderanga Jr. RURAL LABOUR MARKETS, TRANSACTION COST AND FERTIIITY.

8617C Fried, Joel and Peter Howitt. FISCAL DEFICITS, INTERNATIONAL TRADE AND WELFARE.

8618C Trela, Irene, John Whalley, and Randy Wigle. INTERNATIONAL TRADE IN AGRICULTURE: DOMESTIC POLICIES, TRADE CONFLICTS, AND NEGOTIATING OPTIONS. 
8619C Markusen, James R. and Anthony J. Venables. TRADE POLICY WITH INCREASING RETURNS AND IMPERFECT COMPETITION: CONTRADICTORY RESULTS FROM COMPETING ASSUMPTIONS.

8620C Hunter, Linda and James R. Markusen. PER-CAPITA INCOME AS A DETERMINANT OF TRADE.

8621C Jones, Rich and John Whalley. A CANADIAN REGIONAL GENERAL EQUILIBRIUM MODEL AND SOME APPLICATIONS. 